University of South Florida

DIGITAL COMMONS @ UNIVERSITY OF SOUTH FLORIDA
Digital Commons @ University of South Florida

7-1-2016

\title{
Integrated Approaches to EV Charging Infrastructure and Transit System Planning
}

CUTR

Follow this and additional works at: https://digitalcommons.usf.edu/cutr_nctr

\author{
Recommended Citation \\ "Integrated Approaches to EV Charging Infrastructure and Transit System Planning," National Center for \\ Transit Research (NCTR) Report No. CUTR-NCTR-RR-2016-06, Center for Urban Transportation Research, \\ University of South Florida, 2016. \\ DOI: https://doi.org/10.5038/CUTR-NCTR-RR-2016-06 \\ Available at: https://scholarcommons.usf.edu/cutr_nctr/42
}

This Technical Report is brought to you for free and open access by the National Center for Transit Research (NCTR) Archive (2000-2020) at Digital Commons @ University of South Florida. It has been accepted for inclusion in Research Reports by an authorized administrator of Digital Commons @ University of South Florida. For more information, please contact digitalcommons@usf.edu. 


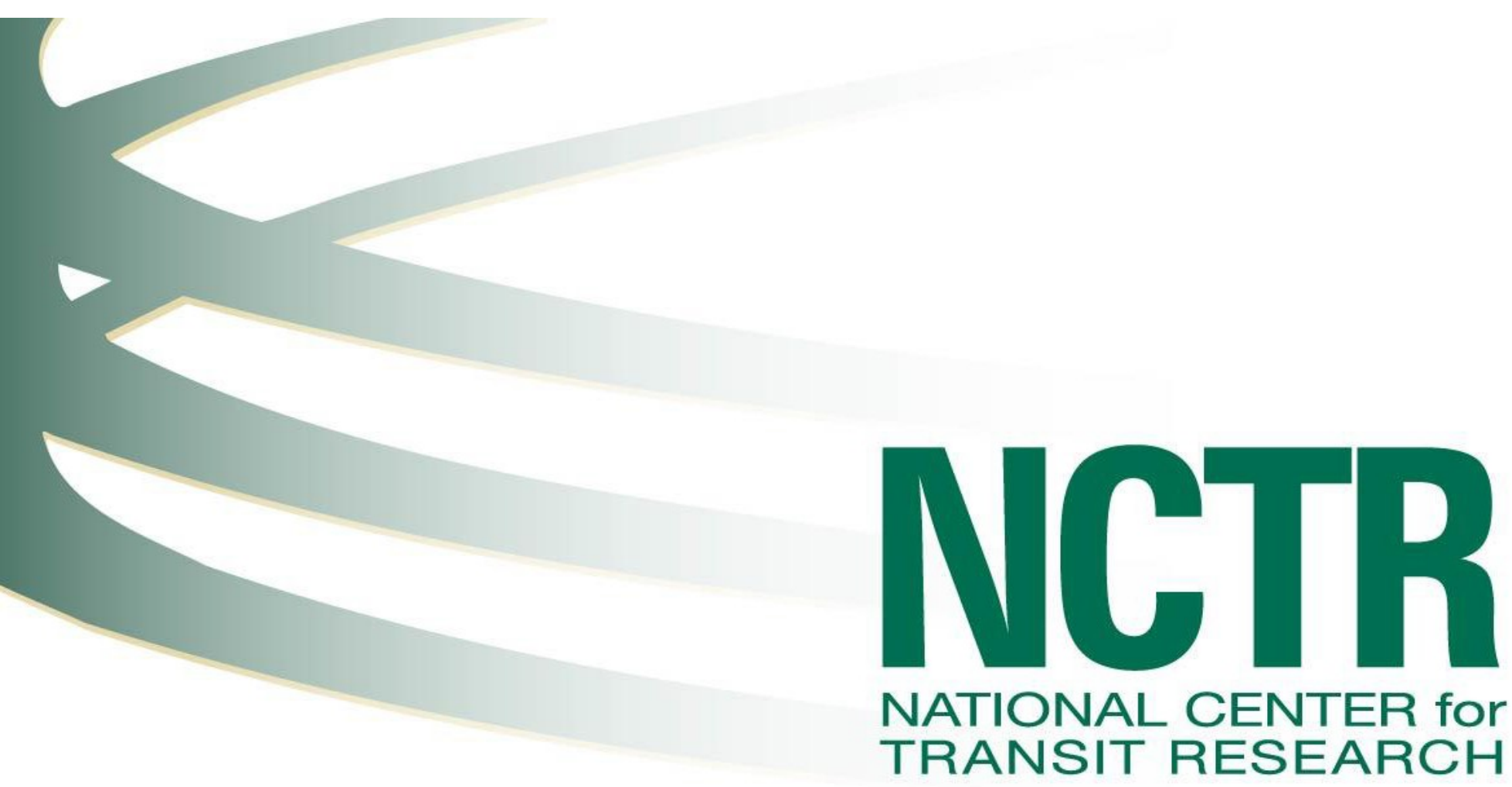

\section{Integrated Approaches to EV Charging Infrastructure and Transit System Planning}

Final Report

July 2016

Project No. 2117-9060-02-C

PREPARED FOR

National Center for Transit Research (NCTR) 


\section{Integrated Approaches to EV Charging Infrastructure and Transit System Planning}

Final Report

Prepared for:

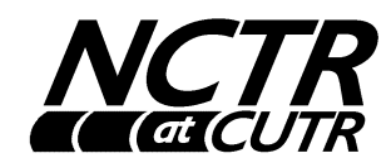

National Center for Transit Research

University of South Florida

Joel Volinski, Project Manager

Prepared by:

Ning Ai, Ph.D.

Assistant Professor, Dept. of Urban Planning and Policy

Research Assistant Professor, Inst. for Environmental Science and Policy

University of Illinois at Chicago

(312) 4139786

ain@uic.edu

July 2016 


\section{Disclaimer}

The contents of this report reflect the views of the authors, who are responsible for the facts and the accuracy of the information presented herein. This document is disseminated under the sponsorship of the University of South Florida's National Center for Transit Research (NCTR) in the interest of information exchange. The University of South Florida and the National Center for Transit Research assume no liability for the contents or use thereof.

The opinions, findings, and conclusions expressed in this publication are those of the authors and not necessarily those of the National Center for Transit Research. 
TECHNICAL REPORT STANDARD TITLE PAGE

\begin{tabular}{|c|c|c|}
\hline 1. Report No. & 2. Government Accession No. & 3. Recipient's Catalog No. \\
\hline \multirow{2}{*}{\multicolumn{2}{|c|}{$\begin{array}{l}\text { 4. Title and Subtitle } \\
\text { Integrated Approaches to EV Charging Infrastructure and Transit System Planning }\end{array}$}} & $\begin{array}{l}\text { 5. Report Date } \\
\text { July } 2016\end{array}$ \\
\hline & & 6. Performing Organization Code \\
\hline \multicolumn{2}{|l|}{$\begin{array}{l}\text { 7. Author(s) } \\
\text { Ning Ai, Ph.D. }\end{array}$} & 8. Performing Organization Report No. \\
\hline \multirow{2}{*}{\multicolumn{2}{|c|}{$\begin{array}{l}\text { 9. Performing Organization Name and Address } \\
\text { University of Illinois at Chicago } \\
\text { Urban Transportation Center } \\
412 \text { South Peoria Street, Suite } 340 \\
\text { Chicago, IL } 60607-7064\end{array}$}} & 10. Work Unit No. (TRAIS) \\
\hline & & $\begin{array}{l}\text { 11. Contract or Grant No. } \\
2117-9060-02-C\end{array}$ \\
\hline \multirow{2}{*}{\multicolumn{2}{|c|}{$\begin{array}{l}\text { 12. Sponsoring Agency Name and Address } \\
\text { National Center for Transit Research } \\
\text { Center for Urban Transportation Research } \\
\text { University of South Florida } \\
4202 \text { East Fowler Avenue, CUT100, Tampa, FL 33620-5375 }\end{array}$}} & 13. Type of Report and Period Covered \\
\hline & & 14. Sponsoring Agency Code \\
\hline
\end{tabular}

15. Supplementary Notes

\section{Abstract}

This study provides policy insights into integrating electric vehicle (EV) infrastructure development with transit systems. It explores opportunities related to underutilized parking spots that are suitable for both EV charging and transit connections, either on site or in proximity to transit stations. Distinct from the existing practice, the study takes into account both work trips and activity based trips (ABT), which involves multiple trip segments/purposes on commuting trips. To advocate for an active role of the public sector in the integrated EV-transit design, it proposes a generic planning model for siting EV charging either on site or in proximity to transit stations. To implement the proposed planning process, the study developed a Suitability Index (SI) for EV charging station siting in connection to transit stations, discusses anticipated impacts of implementing the integrated EV-Transit programs, and quantifies the environmental impacts of anticipated travel behavior changes. Through case studies, the project reviewed the existing programs that integrate EV charging infrastructure with transit systems, quantitatively applies the proposed planning framework in the Chicago metropolitan region and derives the SI rating for commuter rail stations (for work trips) and shopping centers close to transit stops (for ABT trips).

\begin{tabular}{|l|l|l|l|}
\hline \multicolumn{2}{|l|}{ 17. Key Words } & \multicolumn{1}{l|}{ 18. Distribution Statement } \\
\hline $\begin{array}{l}\text { 19. Security Classif. (of this report) } \\
\text { Unclassified }\end{array}$ & $\begin{array}{l}\text { 20. Security Classif. (of this page) } \\
\text { Unclassified }\end{array}$ & $\begin{array}{l}\text { 21. No. of Pages } \\
45\end{array}$ & 22. Price \\
\hline
\end{tabular}

Form DOT F 1700.7 


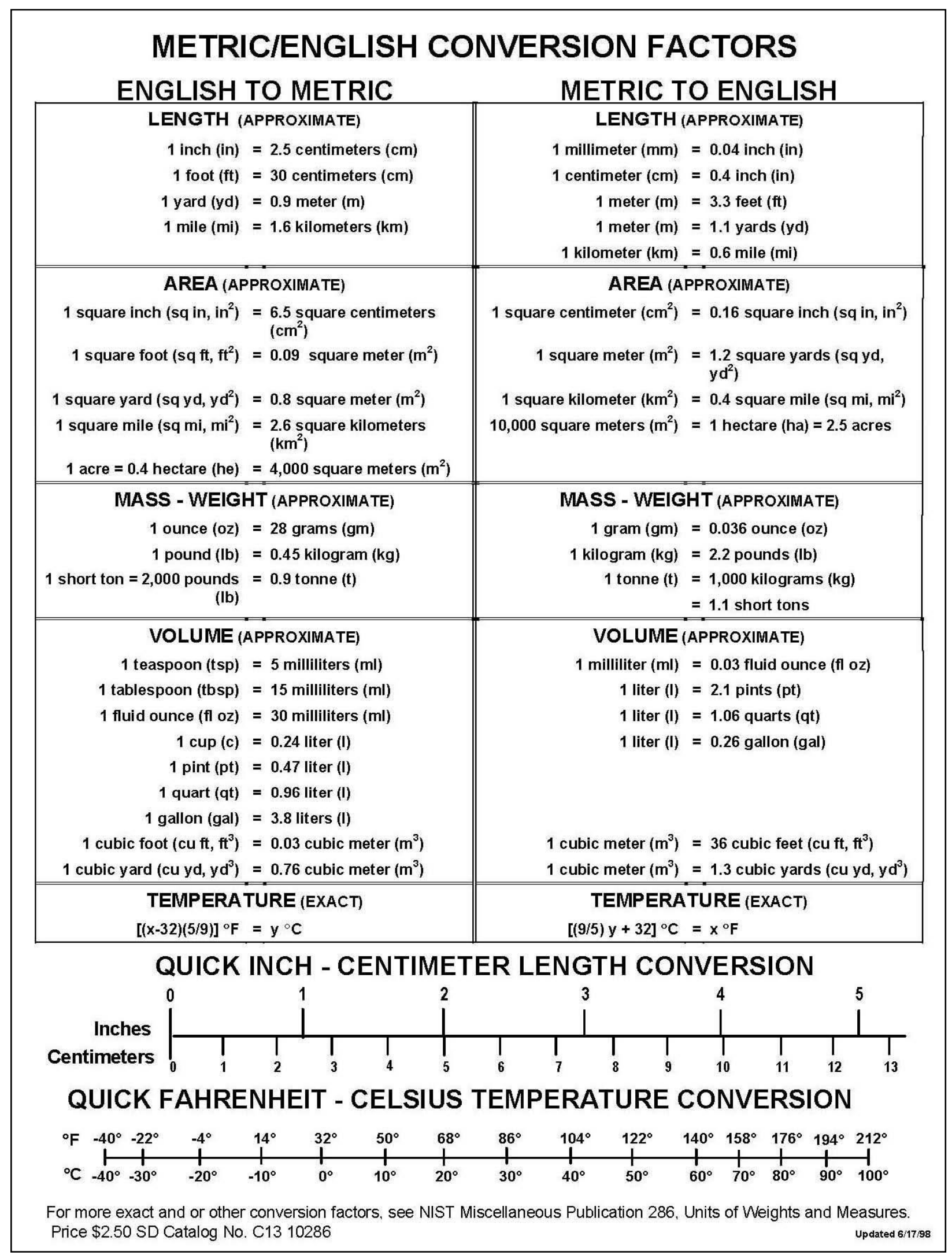




\section{TABLE OF CONTENTS}

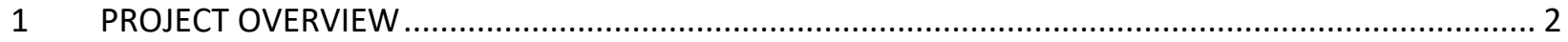

2 EV MARKET AND CHARGING INFRASTRUCTURE DEVELOPMENT …............................................ 3

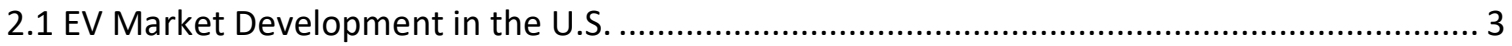

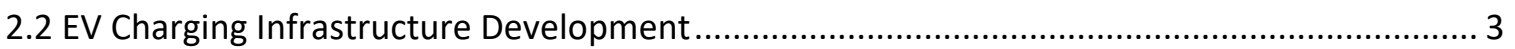

3 EXISTING PROGRAMS THAT INTEGRATE EV INFRASTRUCTURE WITH TRANSIT SYSTEM PLANNING . 8

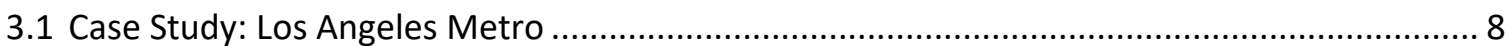

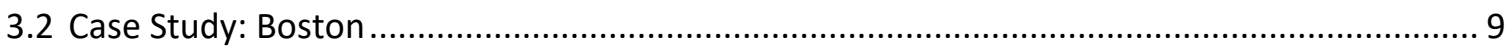

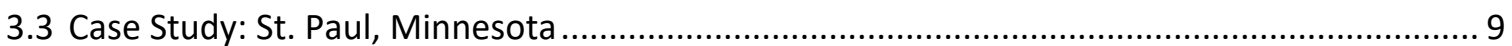

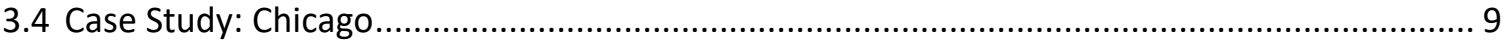

4 PLANNING FOR INTEGRATED EV INFRASTRUCTURE AND TRANSIT SYSTEMS: A FRAMEWORK ........ 11

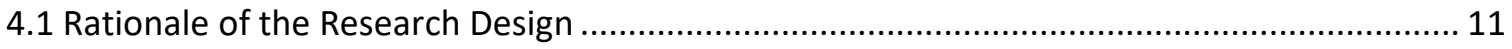

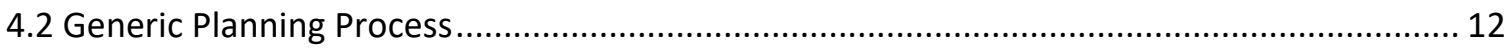

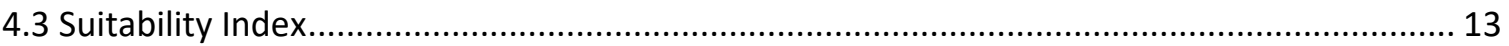

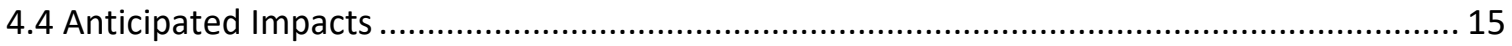

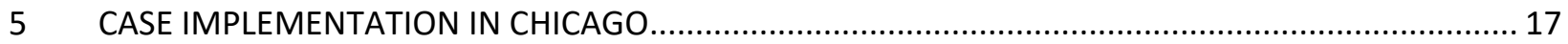

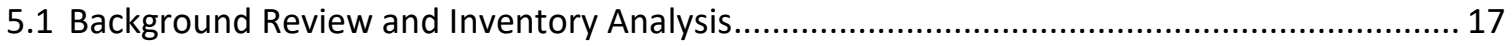

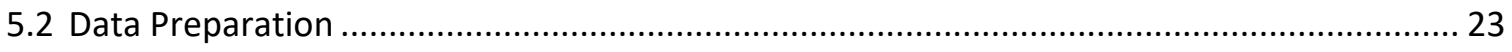

5.3 Results of Top Recommended Location for EV Charging: P\&R Scenario ................................ 24

5.4 Results of Top Recommended Location for EV Charging: ABT Scenario ................................. 26

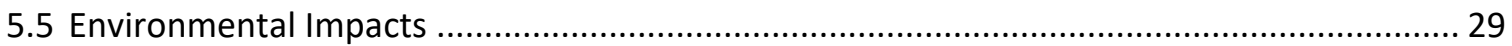

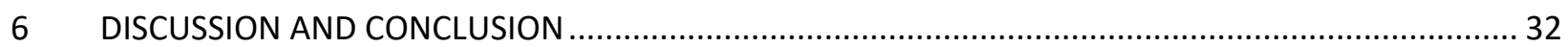

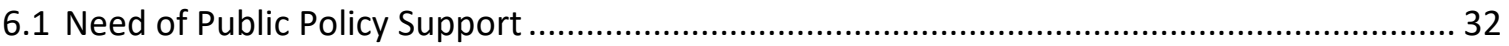

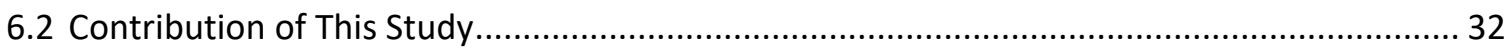

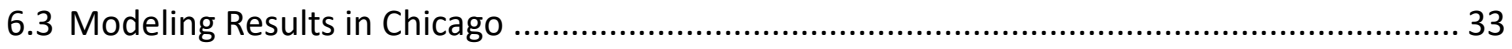

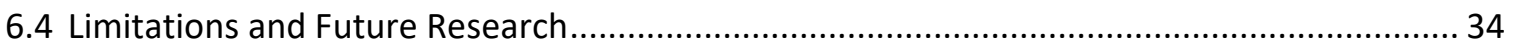

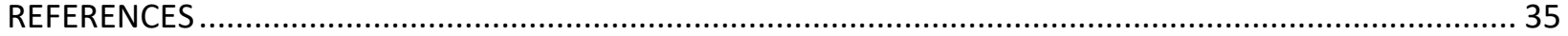

\section{LIST OF FIGURES}

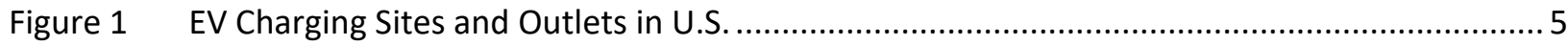

Figure 2 Anticipated Benefits of Integrated Planning of EV Charging Infrastructure ........................ 10

Figure 3 Planning Process for Siting EV Charging Station ........................................................... 20

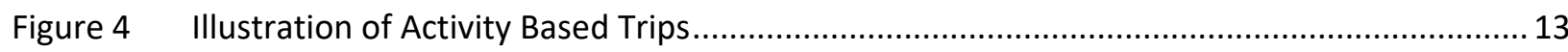

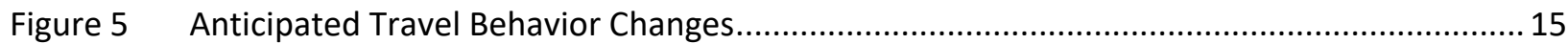

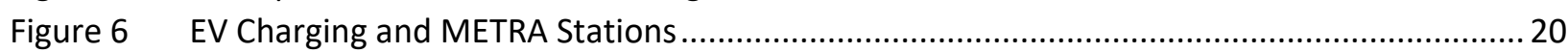

Figure $7 \quad$ EV Charging Stations vs. EV Ownership by ZIP Code in Chicago Metro ................................2 21

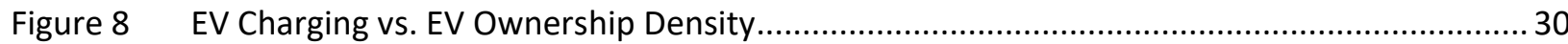

Figure 9 Top 10 Recommended EV Charging Location at METRA P\&R............................................. 25

Figure 10 Commercial Centers as Potential Off-Site P\&R near METRA Stations ..................................2 27

Figure 11 Top 10 Recommended EV Charging Location at Shopping Center ......................................28 


\section{LIST OF TABLES}

Table 1 Characteristics of Level 1, 2, and DC Charging Stations .................................................. 4

Table $2 \quad$ EV Charging Station Cost Estimates (2011) ................................................................. 4

Table 3 Research Hypotheses and Supporting Literature .............................................................. 11

Table 4 Anticipated Impacts of EV-Transit Integrated System Design............................................ 16

Table 5 Regional Commuting Trip Characteristics ................................................................... 18

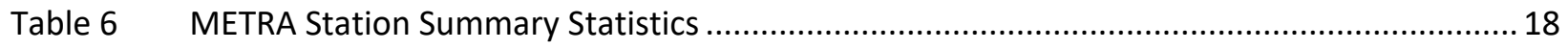

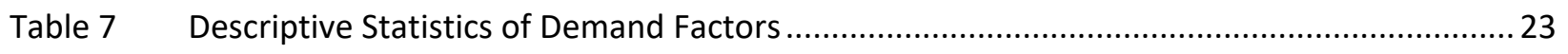

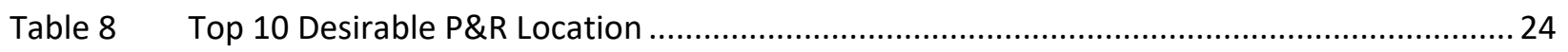

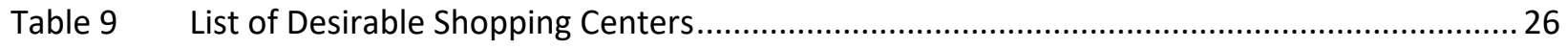

Table 10 Emission Factors Suggested by EPA, 2015 (Kg/Mile) …......................................................2 29

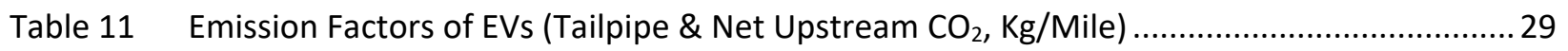

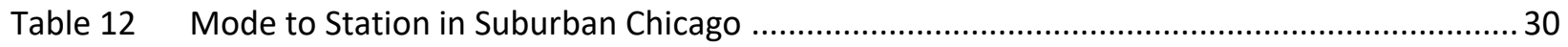

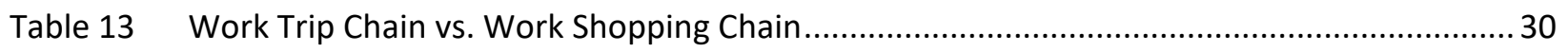

Table 14 Environmental Impact of Anticipated Changes in Travel Behavior........................................ 31 


\section{ACKNOWLEDGMENTS}

This research is funded by the United States Department of Transportation through the National Center for Transit Research within the Center for Urban Transportation Research at the University of South Florida and a grant through the University of Illinois at Chicago Chancellor's Discovery Fund for Multidisciplinary Research. The authors would like to acknowledge the assistance from Anthony Farruggia, Jeff Griffin, and Thomas Kirn and the comments from Dr. P. S. Sriraj and anonymous reviewers.

\section{Principal Investigator}

Ning Ai, Ph.D.

Assistant Professor, Dept. of Urban Planning and Policy

Research Assistant Professor, Inst. for Environmental Science and Policy University of Illinois at Chicago

(312) 413-9786

ain@uic.edu

\section{Research Assistants}

Junjun Zheng

Master of Urban Planning and Policy, Expected in August 2016

University of Illinois at Chicago

jzheng25@uic.edu

Xiaochen Chen

Master of Urban Planning and Policy, Expected in May 2017

University of Illinois at Chicago

xchen203@uic.edu 


\section{EXECUTIVE SUMMARY}

First and last mile accessibility can often be a challenge for transit riders, especially for suburban commuters. Park-and-ride (P\&R) design facilitates transit uses, improves accessibility to stations, and improves systems services. Combining the use of electric vehicles (EV) and transit can further reduce reliance on petroleum vehicles, thereby reducing greenhouse emissions. Such a multi-modal trip also reduces the need for long-distance driving and thus promotes EV adoption. Existing applications of the integrated design of EV infrastructure and transit systems, however, are limited. Concerns can involve both EV charging infrastructure availability and existing P\&R capacity, as well as financial resources and policy support.

The aim of this empirical study is to provide policy insights into integrating EV infrastructure development with transit systems. While the existing EV charging structure has often been driven by the private sector to facilitate EV adoption, this study promotes transit uses and EV adoption at the same time. With a focus on multi-modal trips, this study explores opportunities related to underutilized parking spots that are suitable for both EV charging and transit connections, either on site or in proximity to transit stations.

Distinct from the existing practice, this study takes into account both work trips and activity based trips (ABT), which involves multiple trip segments/purposes on commuting trips. In particular, large shopping centers are selected as a potential opportunity to provide additional capacity for weekday parking and EV charging. This allows for the combination of commuting and shopping trips to reduce total vehicle miles travelled.

To advocate for an active role of the public sector in the integrated EV-transit design, this study proposes a generic planning model for siting EV charging either on site or in proximity to transit stations. To implement the proposed planning process, this study develops a Suitability Index (SI) for EV charging station siting in connection to transit stations, discusses anticipated impacts of implementing the integrated EV-Transit programs, and quantifies the environmental impacts of anticipated travel behavior changes.

Through case studies, this project reviews the existing programs that integrate EV charging infrastructure with transit systems. Quantitatively, this study applies the proposed planning framework in the Chicago metropolitan region and derives the SI rating for commuter rail stations (for work trips) and shopping centers close to transit stops (for ABT trips). The top ten desirable P\&R locations and the top ten ABT locations for EV public charging are identified. Lastly, environmental impacts in terms of carbon emissions are estimated and compared across various travel modes and trip scenarios (i.e., P\&R and ABT). All data variables that are adopted in this study are from publicly accessible sources and thus can be adapted in other regions. 


\section{PROJECT OVERVIEW}

First and last mile accessibility can often be a challenge for transit riders, and especially for suburban commuters. The gaps between destinations and stations often hinder the growth of transit ridership and contribute to system-wide inefficiency. In the 1930s, the park-and-ride (P\&R) concept was introduced to connect personal vehicles with high-occupancy-vehicles (Noel 1988). Such a multi-modal system facilitates transit use, improves accessibility to stations and increases transit demand, causing transit agencies to provide better services (Stieffenhofer, Barton, and Gayah 2015). Later design guidelines and related studies facilitated the adoption and expansion of P\&R across the U.S. (Noel 1988, Parkhurst 1999, Spillar 1997).

The multi-modal system with P\&R availability also helps shorten an individual's daily driving distance so that alternative fuel vehicles (AFVs), such as electric vehicles (EVs), become feasible. Existing studies demonstrate that EVs can improve fuel economy, abate air pollution, reduced reliance on petroleum, improve energy security, and offer a lower vehicle life-cycle cost (Anair and Mahmassani 2012, Bradley and Frank 2009, Eberle and von Helmolt 2010, Offer et al. 2010, Shen et al. 2015, Tessum, Hill, and Marshall 2014). However, widespread EV adoption is constrained by the perception of limited driving range between charges and inadequate accessibility to EV charging infrastructure (Egbue and Long 2012, Lutsey 2015).

Siting EV charging infrastructure on transit P\&R facilities can facilitate EV adoption by improving access to public charging, and, potentially, promote transit ridership (Block et al. 2015, Egbue and Long 2012). However, there are only limited applications of such integrated design. Among the few metropolitan areas (e.g., Los Angeles, Boston, San Diego, Seattle, and St. Paul/Minneapolis) that have led the implementation of such projects, the planning process, siting criteria, and system performance have not been systematically documented.

The goal of this study is to explore integrated approaches to EV charging infrastructure and transit system planning. With a focus on system efficiency, this study specifically explores opportunities related to underutilized parking spots that are suitable for both EV charging and transit connections. Coupling these opportunities with the existing and potential demand of EV ownership, this study develops a Suitability Index (SI) for the siting of EV charging stations. When P\&R space is limited and EV charging demand is high, alternative parking spaces in the proximity of transit stations are also evaluated. Environmental impacts of all proposed scenarios are evaluated in terms of vehicle miles traveled (VMT) and ensuing emissions.

This report consists of six sections. The second section, which follows this overview, reviews the development of the EV market and charging infrastructure planning in the U.S. The third section reviews existing transit programs that include an EV charging infrastructure. The fourth section develops a SI and discusses the generic planning and modeling framework. The fifth section illustrates a case implementation for Chicago region. The final section discusses the planning implications of this approach as well as the limitations of this study. 


\section{EV MARKET AND CHARGING INFRASTRUCTURE DEVELOPMENT}

\subsection{EV Market Development in the U.S.}

The U.S. has witnessed an increasing popularity of EVs. A one-million-EV goal, pledged by President Barack Obama in 2011, represents a milestone toward reducing oil dependence and greenhouse gas emissions, increasing energy security, improving fuel economy, and benefiting the environment. Up to 2015, 4.3 million EVs have been sold in the U.S. (U.S. Department of Energy 2015b).

There are three general models of EVs: Battery EVs (BEVs), which operate solely upon a system of onboard batteries and must be plugged into an outlet or charging facility for recharges; Plug-in Hybrid Electric Vehicles (PHEVs), which operate mostly by batteries but also include an internal combustion engine as a back-up or supplementary source; and Hybrid EVs (HEVs), which have both a conventional internal combustion engine and an electric propulsion system. HEVs are gasoline powered and cannot be recharged by plugging in to the power grid. Therefore, BEVs and PHEVs, or Plug-in EVs (PEVs), are the target of this study. PEVs are also a major driver of increasing EV sales. Annual PEV sales rapidly increased from 18,000 in 2011 to 114,000 in 2015, despite the drop in oil price, which historically showed a negative correlation with the EV sales (U.S. Department of Energy 2015c). It is projected that annual PEV sales can reach $20 \%$ of new light-duty vehicle sales in 2050 (Babaee, Nagpure, and DeCarolis 2014), compared to less than $1 \%$ as of 2015 .

Socioeconomic characteristics and the history of vehicle ownership have been found associations with local EV adoption (Curtin, Shrago, and Mikkelsen 2009, Todd and Thorstensen 2013). Survey-based studies also found that early adopters are sensitive to government incentives and overall cost considerations (Vyas and Hurst 2013). Therefore, communities that actively plan for charging infrastructure and offer purchase incentives can strengthen the appeal to potential EV buyers.

\subsection{EV Charging Infrastructure Development}

\subsubsection{Type of EV Charging Stations}

Nationwide, there are 15,710 EV charging sites and nearly 35,000 outlets (U.S. Department of Energy 2015a). Many EV charging sites are clustered in large urban areas and/or regions and Interstate corridors. EV charging sites may adopt various charger types (Level 1, Level 2, and Level 3), which differ by electricity requirements, equipment installation needs, and charging times. Each charger type is suited for specific charging locations/situations. The equipment and installation costs also vary by charger type, although EV infrastructure costs in general are projected to decline by 1.5\%-2\% per year through 2050 (Greene Sr 2015). 
Level 1 Chargers are thought to be best used where drivers will be parked for long periods of time, including homes and at their work place. Since Level 1 charging does not require higher voltage than a typical home or business already has, the installation cost is low and it can be easily adopted by homeowners or businesses (U.S. Department of Energy 1995a, b, CALSTART 2013). But a full charge can take up to 24 hours.

Level 2 Chargers, with a full charging time of 4-8 hours, are also suitable for homes and businesses, but require higher voltage and professional installation. Even with these added costs, Level 2 chargers can be suitable for overnight charging at residences if possible (Frades 2014). Additionally, Level 2 is recommended for locations where people are parked for several hours, such as shopping malls, commuter lots, and downtown parking lots (Francfort and Brion Bennett 2015).

Level 3 Chargers can charge a car in minutes, and thus are also referred to as Fast DC Chargers. If installed along interstate highways at rest-stops, Level 3 chargers can help support inter-city travels by extending the range of EVs (Francfort and Brion Bennett 2015).

Additionally, Level 3 chargers can be used as supplemental daytime charging for fleet vehicles or personal vehicles at shopping centers (Frades 2014). Compared to Level 1 and 2 chargers, Level 3 fast chargers require a larger electrical connector and much higher costs for equipment and installation. A comparison of the three levels of chargers is provided in Table 1 (key characteristics) and Table 2 (cost estimates) below.

Table 1 Characteristics of Level 1, 2, and DC Charging Stations

\begin{tabular}{lcccc}
\hline Charger Type & Voltage & Current & Power & $\begin{array}{c}\text { Time to Fully } \\
\text { Charge* }\end{array}$ \\
\hline Level 1 AC & $120 \mathrm{~V}$ & $8-12 \mathrm{amps}$ & $1.0-1.4 \mathrm{~kW}$ & $8-24$ hours \\
Level 2 AC & $240 \mathrm{~V}$ & $15-100 \mathrm{amps}$ & $3.6-19.2 \mathrm{~kW}$ & $4-8$ hours \\
Level 3 DC & $480-600 \mathrm{~V}$ & $80-120 \mathrm{amps}$ & $20-72 \mathrm{~kW}$ & 30 minutes \\
Fast-Charger & & & & \\
\hline
\end{tabular}

* For EVs with a usable battery capacity of approximately 24 kilowatts per hour (kWh). Source: U.S. Department of Energy (Frades 2014).

Table 2 EV Charging Station Cost Estimates (2011)

\begin{tabular}{lrrr}
\hline \multicolumn{1}{c}{ Charger Type } & Equipment Cost & Installation Cost & \multicolumn{1}{c}{ Total Cost } \\
\hline Level 1 & $\$ 450-\$ 950$ & $\$ 0-\$ 500$ & $\$ 450-\$ 1,450$ \\
Level 2 (Home) & $\$ 490-\$ 1,200$ & $\$ 300-\$ 2,000$ & $\$ 790-\$ 3,200$ \\
Level 2 (Public) & $\$ 1,875-\$ 4,500$ & $\$ 1,000-\$ 10,000$ & $\$ 2,875-\$ 14,500$ \\
Level 3 & $\$ 17,000-\$ 44,000$ & $\$ 7,000-\$ 50,000$ & $\$ 24,000-\$ 94,000$ \\
\hline
\end{tabular}

Source: National Research Council (Chapin et al. 2013, Greene Sr 2015) 
At present, more than $80 \%$ of total EV charger sites are Level 2 (Figure 1). Level 1 and Level 3 chargers have about the same number of sites, but the total number of Level 3 charger outlets is higher than that of Level 1 . The reason is that Level 3 are mostly public charging points with multiple outlets, while Level 1 are deployed by many private residential sites with one outlet only.

Figure 1 EV Charging Sites and Outlets in U.S.

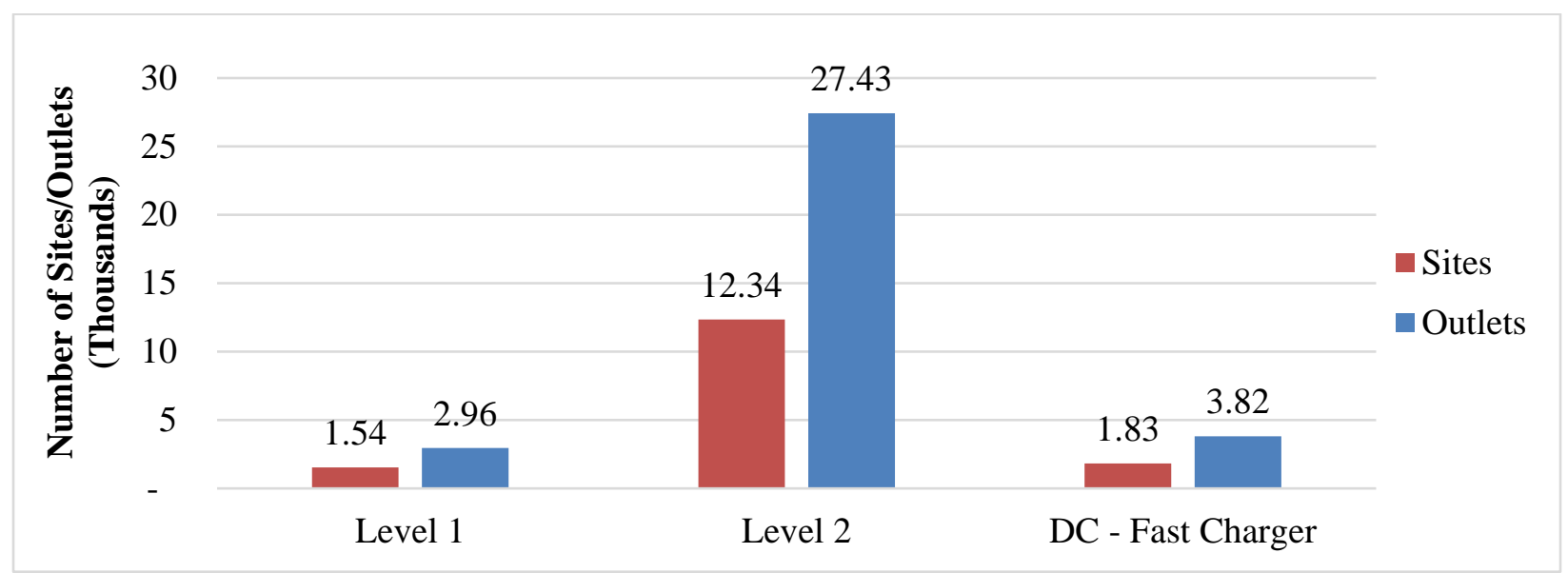

Source: Alternative Fuel Data Center (U.S. Department of Energy 2015a)

\subsubsection{Role of Public vs. Private Sector in EV Charging Infrastructure Development}

The development of EV charging infrastructure has been driven by both the public and private sectors. Early amendments, such as the EISA 2007 and EPAct 2005/2007, have improved vehicle acquisition requirements and promoted renewable fuel facility installation at federal proporties to support EV acquisitions. The Moving Ahead for Progress in the 21st Century Act (MAP-21) of 2012 further promoted EV charging stations (FHA 2015). Recently, the Fixing America's Surface Transportation Act (Fast Act) of 2015 extended federal tax credits for household EV charging systems and proposed a plan for nationwide alternative fuel station installation. Some federal agencies are now required to install electric vehicle supply equipment (EVSE) to encourage employees to use EVs. These transportation acts continued the Congestion Mitigation and Air Quality (CMAQ) improvement program to curb negative environmental impacts.

Several federal stimuli after the 2008 recession also addressed EV development via vehicle purchase tax rebate programs. For example, the American Recovery and Reinvestment Act of 2009 provided $\$ 400$ million for selected communities to plan EV charging infrastructure as a Transportation Electrification Initiative. The 2010 Tax Relief Act, the American Taxpayer Relief Act of 2012, the Tax Increase Prevention Act of 2014, and the Consolidated Appropriations Act of 2016 also extended and reinstated tax credits for AFVs and EVs (National Renewable Energy Laboratory 2015). 
EV makers have also contributed to the EV infrastructure development. For example, as of July 2016, Tesla Motors, Inc. (Tesla) has placed more than 600 fast charging stations with 4,200 Superchargers (Level-3 equivalent) across the U.S. Tesla plans to extend the network so that $98 \%$ of Americans will be no more than 100 miles from a fast charger (Tesla 2016).

\subsubsection{Siting EV Charging Stations}

Price, attainability, smart grid features, and the bidder's overall offering packages are often cited as important factors in the EV infrastructure siting process. However, little information is available that shows a formal process for selecting a location to install EV infrastructure. No federal or state laws have yet regulated or guided the placement of EV infrastructure. Economic incentives for public charging often do not explicitly define the placement location through a formal planning process; the location is largely determined by interested parties.

Since there is no central planning of EV charging stations, the type and location of EV charging infrastructure are largely determined by market forces. Currently, half of EV users charge their EVs exclusively at home (Francfort and Brion Bennett 2015). According to the U.S. DOE, a Massachusetts program found that people charge at home most often because it is most cost-effective, whereas public charging facilities often have fees that make it more costly (U.S. Department of Energy 1995b). Evolving technologies have also enabled online-permitting, installation of separate metered electric service, and Wi-Fi for EV data tracking, which is often required for state rebate programs (The EV Project 2015). In contrast to single-family residences, multi-unit dwellings (MUDs) present further challenges for residential charging. Establishing permissions from building owners, as well as responsibilities for installation, maintenance, insurance, electrical capacity and payment can be difficult. Additionally, parking structure layouts, electricity, and Wi-Fi access can be more difficult in a MUD than a singlehome residence. Lastly, current government rebate programs are often only for drivers, not for building owners, so using rebates to encourage building owners to install EVSE is not an option (Balmin, Bonett, and Kirkeby 2012).

For people charging away from home, the workplace is the most popular location (Francfort and Brion Bennett 2015). Level 1 is thought to be best for companies just starting out or testing charging facilities for their employees (CALSTART 2013). A mix of Level 1 and 2 charging spaces could be appropriate if parking is abundant. Additionally, other factors specific to workplace location and business type should be considered. For example, for a university, Level 1 EVSE spots may be appropriate for full-time staff, while student ESVE might need Level 2 to accommodate their variable schedules (Giles, Ryder, and Lommele 2016).

In conclusion, it appears that current EV programs are prioritizing residential and workplace charging as the key locations for EV chargers. However, the exclusivity and inefficiency of household- and employment-only facilities create barriers to further EV 
adoption. Also, workplace charging tends to encourage more driving on the road (Idaho National Laboratory 2015). Siting EV charging stations on transit stops can potentially overcome some of the logistical challenges of installing public charging, such as charging time and utilization rate, which can complement commuters' schedules and travel routines. There are a few regions that have adopted a systemic approach that places public EV charging stations or charging outlets at transit stations. The perceived benefits of this approach are discussed using case studies in the next section. 


\section{EXISTING PROGRAMS THAT INTEGRATE EV INFRASTRUCTURE WITH TRANSIT SYSTEM PLANNING}

Two main approaches have been adopted for integrating EV infrastructure with public transit: adopting alternative fuel fleets and siting EV charging infrastructure close to transit stops (Adrianzen, Darby, and McCallum 2010, Brecher 2012, MBTA 2014, Mišanović 2013, Tzeng, Lin, and Opricovic 2005). In practice, most of the regional and local EV readiness plans or annual reports have not connected charging with transit planning; only Kansas City and New York City briefly mentioned a transit component (Redenbaugh 2012, Kahn and Ficicchia 2012). This section reviews three existing and fully developed programs: LA, Minneapolis/St. Paul, and Boston. Current practice in Chicago is also reviewed.

\subsection{Case Study: Los Angeles Metro}

Los Angeles, California pioneered America's integration of EV charging with public transit systems. The Los Angeles County Metropolitan Transportation Authority (Metro) decided to install EV charging stations as an effort to reduce greenhouse gas emissions. EV charging stations were first installed at five transit stops in 2013 for "their proximity to major transportation hubs and busy traffic arteries" and funded through a grant of the California Energy Commission (EV Connect 2011). The following year, additional EV chargers were added to another five Metro stations. It costs $\$ 1$ per hour to charge the EV and has a \$3 cap per charge.

The highest concentration of EV chargers are located at Union Station, a major commuter rail and public transit hub. Metro selected the stations to encourage the use of its transit system, including Park \& Ride lots, for travels to and from Downtown LA (LA Metro 2016b). Currently, 39 Level 2 charging units have been installed in 10 stations. Parking fees are waived in lieu of a charging fee (LA Metro 2016a). Membership in EV Connect, the network provider, is required to utilize the EV charging stations. It is worth noting that this program is owned and operated by Metro, rather than Share Point, or Charge-Point, the two largest EV station companies in America.

Although Metro's EV sites have been operating for three years now, the EV charging sites still tend to be underutilized. It can be partially attributed to low ridership on public transit systems in the LA area. Average weekday ridership for rail service is only 339,072 , in contrast to 9.6 million residing in the region (LA Metro 2016c). Additional incentives and promotional programs need to target both public transit and EV charging locations at Park and Ride lots. In addition, the location of EV charging sites may need to be re-evaluated at times, given the rapid development of the EV market and the dynamics of EV ownership. 


\subsection{Case Study: Boston}

As the regional transportation agency in Boston, the Massachusetts Bay Transportation Authority (MBTA) maintains a network of heavy rail, bus, maritime, and streetcar infrastructure, which serves over 4.8 million people in "176 cities with an area of 3,249 square miles" (MBTA 2016). As part of an energy efficiency program and customer service initiative, MBTA installed 30 EV chargers at Park and Ride lots at MBTA stations. These stations give priority parking spaces and free charges to people with electric vehicles. It is estimated that this program has "prevented over 32,956 lbs. of greenhouse gases from discharging into the atmosphere" (MBTA 2014). Although it is not clear how the estimate was made, it appears that the MBTA acknowledges that EV charging stations are not a final solution to combating environmental degradation, but rather a tool or asset for the public.

\subsection{Case Study: St. Paul, Minnesota}

EV charging infrastructure planning was included in the St. Paul Union Depot revitalization project as an approach to satisfying federal requirements for accommodating Low Emitting \& Fuel Efficient Vehicles. The Union Depot project brought multiple public transportation agencies together to better serve the Minneapolis/St. Paul region and is anticipated to serve over 3.5 million residents of the seven-county metropolitan area.

When completed in 2012, the project installed six 120-volt Level 1 charging stations in the project area. Two stations are in Lot $A$, which has direct access to the passenger terminal. Two stations are in Lot B, which is farther away. Another two are on Wacouta Street, which is an off-site location. The current setup of EV stations is designed to be primarily used for short durations of up to four hours. Users pay for both parking and electricity fees. While it costs the same to refuel, parking fees vary. Lot $A$ and Lot $B$ are more expensive than the spots on Wacouta Street. Compared to similar programs in LA and Boston, the St. Paul Union project seems to provide more convenience than cost incentives for EV users.

\subsection{Case Study: Chicago}

Currently five commuter rail stations are equipped EV charging on their parking lots. They are Aurora Transportation Center, Franklin Park, Des Plaines, Oak Park and Wheeling stations. Most of the EV charging is funded by the Renewable Fuels Development Program at the Illinois Department of Commerce and Economic Opportunity, which facilitates the deployment of Level-2 charging technologies for public use. Most of the chargers were operated by a private network (e.g. Charging Point Company), which requires memberships to access the network. Transportation planning agencies were not involved in the allocation or implementation process.

At the Aurora Transportation Center, two Level-2 chargers are available to the general public, and four Tesla superchargers are exclusively available for Tesla drivers. It charged \$1.5 
dollars for parking and 11 cents for every kilowatt-hour charged within a 4-hour parking limit (Hebdrick 2014). Other station, such as Franklin Park station, provided free parking for EV drivers. Besides parking costs, EV charging typically costs $\$ 0.5$ to $\$ 1$ per hour (Village of Wheeling Board of Trustees 2012).

In summary, existing programs that integrate EV charging infrastructure and transit systems are still limited and newly implemented. The adoption of such an integrated design is expected to reduce greenhouse emissions and VMT (Figure 2). Connecting EV charging infrastructure with transit systems provides an opportunity for EV drivers to shorten their daily driving distances as well as to provide convenient charging. While it is advantageous for the private sector (including both businesses and households) to continue to invest in EV infrastructure, a more active role of the public sector is still needed.

Figure 2 Anticipated Benefits of Integrated Planning of EV Charging Infrastructure with Transit System

Approaches

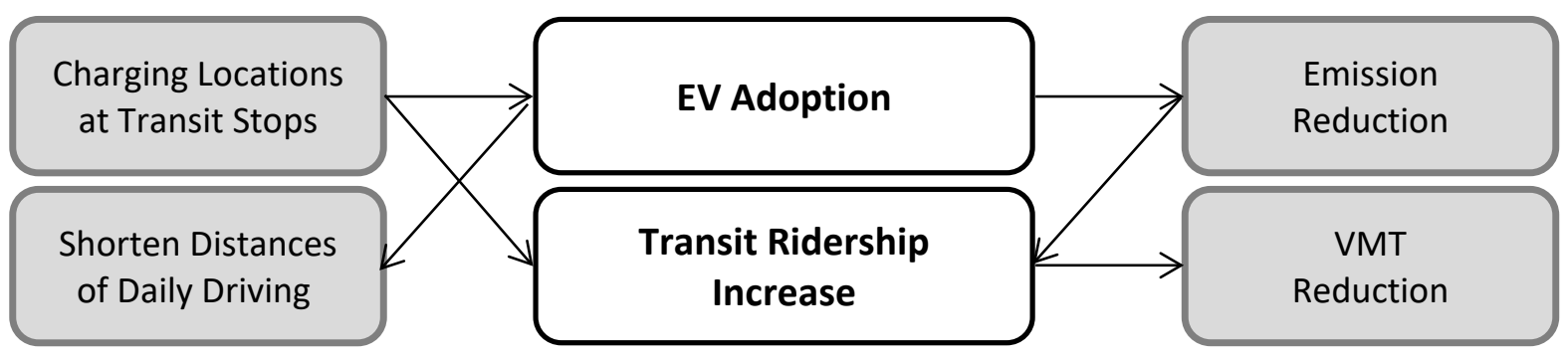




\section{PLANNING FOR INTEGRATED EV INFRASTRUCTURE AND TRANSIT SYSTEMS: A FRAMEWORK}

In reviewing the existing programs discussed in Section 3, we propose a generic planning model for siting EV charging in connection with transit stations. It focuses on promoting multimodal trips that include EV driving and transit use to reduce VMT and emissions. Distinct from existing practice, we take into account both work trips and activity based trips (ABT), which involves multiple trip segments/purposes on commuting trips.

This section discusses the rationale of the project design, a generic planning model for siting EV charging either on site or in proximity to transit stations, the SI that we have developed for EV charging station siting in connection with to transit stations, and anticipated impacts of implementing the planning the integrated EV-Transit programs.

\subsection{Rationale of the Research Design}

The design of this study was built upon the following observations that were revealed by existing empirical analyses, as discussed in Table 3.

Table 3 Research Hypotheses and Supporting Literature

\begin{tabular}{ll}
\hline Hypothesis & Observations and Findings from Previous Studies \\
\hline $\begin{array}{l}\text { Multi-modal trips that combine EV } \\
\text { driving and transit use can be a fit for } \\
\text { suburban commuters. }\end{array}$ & $\begin{array}{l}\text { Many commuters live beyond walking distance } \\
\text { (2.5 to } 5 \text { miles) from the transit station. P\&R users } \\
\text { make up more than half of the total transit } \\
\text { ridership [1]. }\end{array}$ \\
\hline $\begin{array}{l}\text { Installing EV charging equipment at } \\
\text { transit stations can promote EV } \\
\text { adoption. }\end{array}$ & $\begin{array}{l}\text { Additional public EV charging equipment } \\
\text { promoted EV adoption [2] }\end{array}$ \\
\hline & Frequency of charging varies by user; it can be \\
$\begin{array}{l}\text { One charging spot can serve multiple } \\
\text { drivers. }\end{array}$ & $\begin{array}{l}\text { every use, every day, or every week, depending } \\
\text { on individual driving patterns. Not all EV drivers } \\
\text { need to charge on a daily basis [3] }\end{array}$ \\
\hline $\begin{array}{l}\text { Not all P\&R sites have space available for } \\
\text { EV charging. }\end{array}$ & $\begin{array}{l}\text { Current P\&R facilities are already facing space } \\
\text { constraints [4] }\end{array}$ \\
\hline $\begin{array}{l}\text { ABT account for a big proportion of } \\
\text { weekday travels. }\end{array}$ & $\begin{array}{l}\text { About 50\% of working commuters added other } \\
\text { activities on the way to or from work }\end{array}$ \\
\hline $\begin{array}{l}\text { References: [1] (Duncan and Cook 2014, Foote 2000, Kim, Ulfarsson, and Hennessy 2007, Stieffenhofer, Barton, } \\
\text { and Gayah 2015, Turnbull, Pratt, and Evans 2004) [2] (Egbue and Long 2012, Block, Harrison, and Brooker 2015). } \\
\text { [3] (Schoch 2016, Morrissey, Weldon, and O'Mahony 2016).[4] (Duncan and Cook 2014, Stieffenhofer, Barton, and } \\
\text { Gayah 2015).[5] (McGuckin and Srinivasan 2005, O'Kelly 1983). }\end{array}$
\end{tabular}




\subsection{Generic Planning Process}

This study proposes the following planning process to determine desirable locations for EV charging in connection with transit stations (Figure 3). The first is to identify the existing and potential demand of EV charging facilities for commuter rail riders. The demand for EV charging is not only driven by EV ownership, but also the number of commuters who drive EVs from home to transit stations. The existing demand can be evaluated using vehicle registration data and transit statistics. The potential demand can be correlated with the existing demand, as communities showing high rates of EV ownership are most likely to purchase an EV in the near future (Curtin, Shrago, and Mikkelsen 2009, Vyas and Hurst 2013). We also hypothesize that communities experiencing rapid population growth and possessing high rates of $P \& R$ usage show high potential demand for EV charging infrastructure close to transit stations.

Figure 3 Planning Process for Siting EV Charging Station

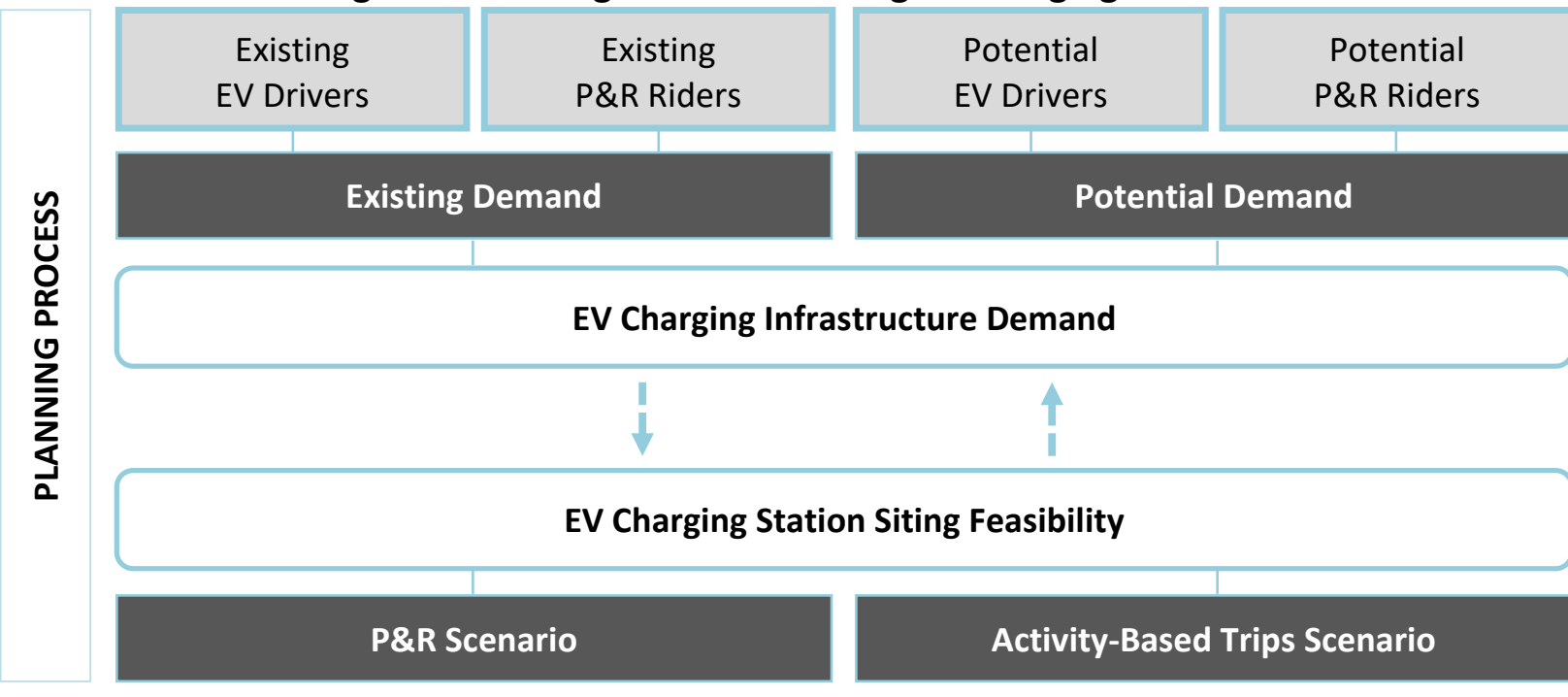

Once existing and potential demand around a station is identified, the next step is to determine the feasibility of siting EV charging outlet at transit stations. As discussed earlier, P\&R facilities are already facing space constraints (Duncan and Cook 2014, Stieffenhofer, Barton, and Gayah 2015). Installing EV charging outlets and reserving parking spots for EV users can create further competition for limited parking space during workdays. Therefore, this study recommends a feasibility analysis of transit stations and excludes those fully utilized or smallscale P\&R sites, especially if the underutilized parking capacity is low (e.g., fewer than 100). In this case, it would help to investigate underutilized parking space during the daytime on weekdays on parcels close to transit stations.

The third step is to evaluate alternative sites close to transit stations if the demand of EV charging infrastructure is determined to be high in the first step. In particular, we recommend an evaluation of large commercial centers near transition stations in an ABT scenario. As 
illustrated in Figure 4, shopping centers are added as a new element to the planning process in the P\&R scenario, which chains residence, workplace, and transit stops. About $50 \%$ of working commuters make stops on the way to or from work (McGuckin and Srinivasan 2005, O'Kelly 1983); commuting and shopping trips can be combined to reduce the total VMT (Frank 2010). Parking lots at those shopping centers tend to be under-utilized during typical work hours (i.e., 9AM to 5PM from Monday to Friday). Therefore, including an ABT scenario in the planning process can be reasonable and provide additional opportunities for siting charging infrastructure near high-demand stations. Meanwhile, the strategy can increase the efficiency of underutilized parking facilities at suburban shopping centers. It is important to note that the travel mode between the shopping center and transit stops may depend on the distance and road conditions; proximity and accessibility to transit stations matter. Shopping centers within walking distance would be preferred. Otherwise shuttle services or bike programs may be needed.

\section{Figure 4 Illustration of Activity Based Trips}

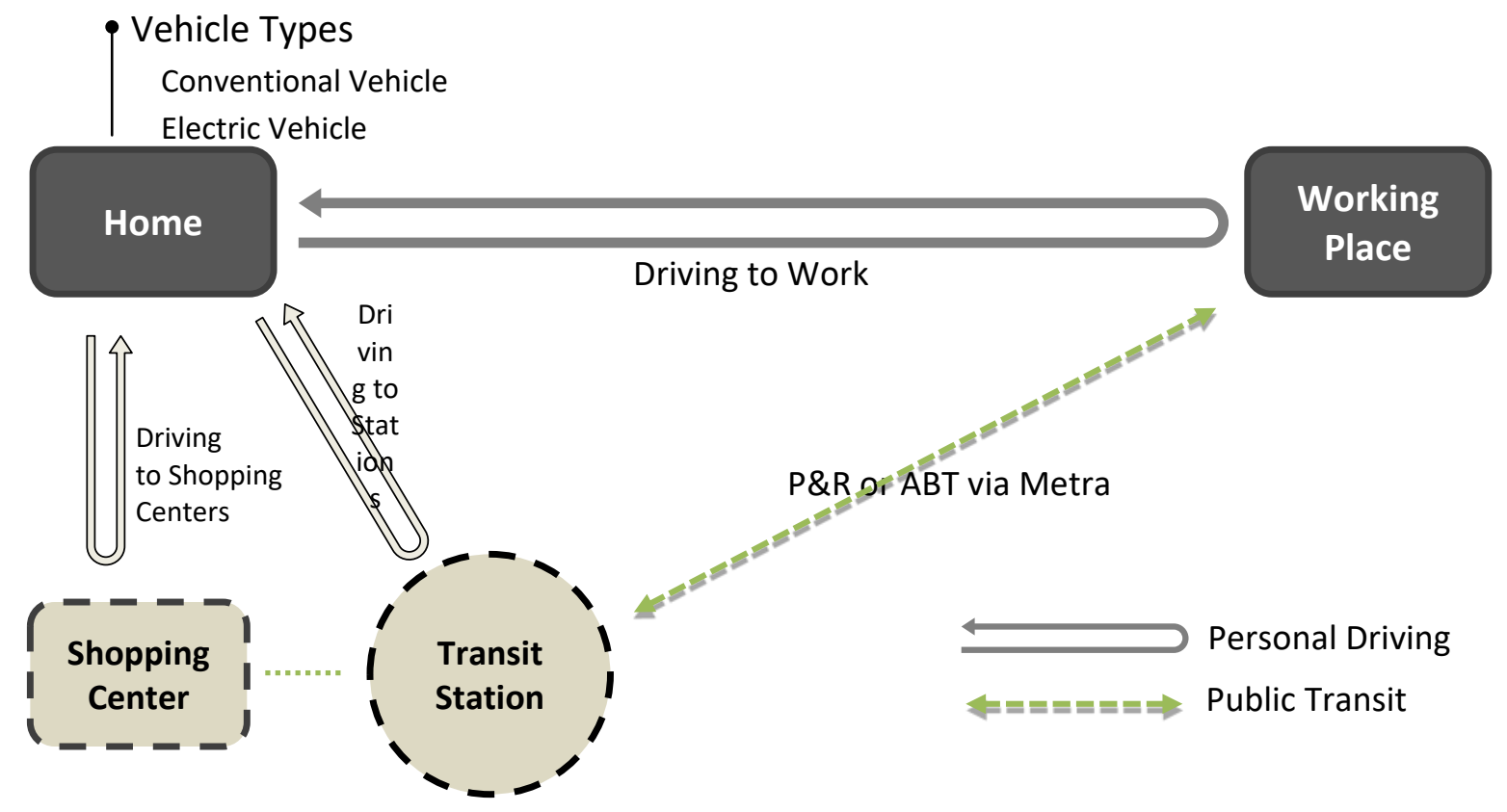

\subsection{Suitability Index}

To implement the planning process discussed in Section 4.2 in a numerical way, we have developed the Suitability Index (SI) that integrates the multiple factors in the planning process (Figure 3). Equation (1) below illustrates the SI calculation for the P\&R scenario and calculates the suitability for transit stations. Equation (2) presents the SI for ABT scenario and calculates the suitability for shopping centers in proximity to transit stations. 


$$
\begin{gathered}
S I_{P \& R}=f\left(E_{E V}, E_{P \& R}, P_{E V}, P_{P \& R}\right) \times f\left(F_{T}\right) \\
S I_{A B T}=f\left(E_{E V}, E_{P \& R}, P_{E V}, P_{P \& R}, D_{T}\right) \times f\left(F_{S C}\right)
\end{gathered}
$$

Where,
SIP\&R: Suitability Index for the P\&R scenario
$S I_{A B T}$ : Suitability Index for the ABT scenario
$E_{E V}$ : Existing EV drivers
$E_{P \& R}:$ Existing $P \& R$ riders
$P_{E V}$ : Potential EV drivers
$P_{P \& R}:$ Potential P\&R riders
$F_{T}$ : Feasibility of parking spots at transit station
$F_{S c}$ : Feasibility of parking spots at shopping center
$D_{T}$ : Distance between shopping center and nearest transit station

Since the variables in Equations (1) and (2) are various in units and scales, we developed the following strategies to create an integrated index. First, we calculated the percentile values of each data point (station) so the values of all data variables were re-created between 0 and 1 . Second, we summed the percentile values of all variables and calculated an average index for each station (or shopping center). Essentially, this equally weighted ranking approach address the heterogeneities among different variables. Thirdly, the feasibility variable $\left(F_{T}\right)$ is defined as a binary variable considering both utilization rates (\%) and parking capacity (in terms of the number of parking spots). If the parking lot has been fully occupied at P\&R sites, the station value is re-coded as 0 ; if it tends to have ample underutilized spots, it is re-coded as 1 . The final $\mathrm{SI}$ value is between 0 and 1 ; the smaller the $\mathrm{SI}$, the more desirable the siting location.

In the ABT scenario, each shopping center can be linked with the nearest transit station, where transit data are available and EV demand data may have been compiled in the first step of the planning process (Section 4.2). Then the distance between each shopping center and the closet transit station was calculated as the crow flies. Assuming shopping centers further than two miles from the nearest transit station are inefficient in the ABT scenario, the distance values over 2 miles were all recoded as 0 . To rank the desirability of shopping centers by its distance to transit stations, the distance values from zero- to two-miles were uniformly mapped to the range of 0 to 1 ; the shorter the distance, the higher the re-coded value. For example, 0 miles is recoded as 1,1 mile as 0.5 , and 2 miles as 0 . The average value of all variables for each shopping center represents the desirability for installing the EV chargers. 


\subsection{Anticipated Impacts}

To measure the potential impact of an integrated EV-Transit design, planners need to understand the anticipated travel behavior changes. While both the P\&R and ABT scenarios are anticipated to change the behavior of conventional vehicle (CV) drivers, they are applicable for different trip patterns. So the baseline scenario is different and anticipated travel behavior changes also vary (Figure 5). When comparing the before and after effects, we recommend a separate process for the $P \& R$ from $A B T$ scenarios and adopting trip chains as the unit of analysis, if measured quantitatively.

Figure 5 Anticipated Travel Behavior Changes

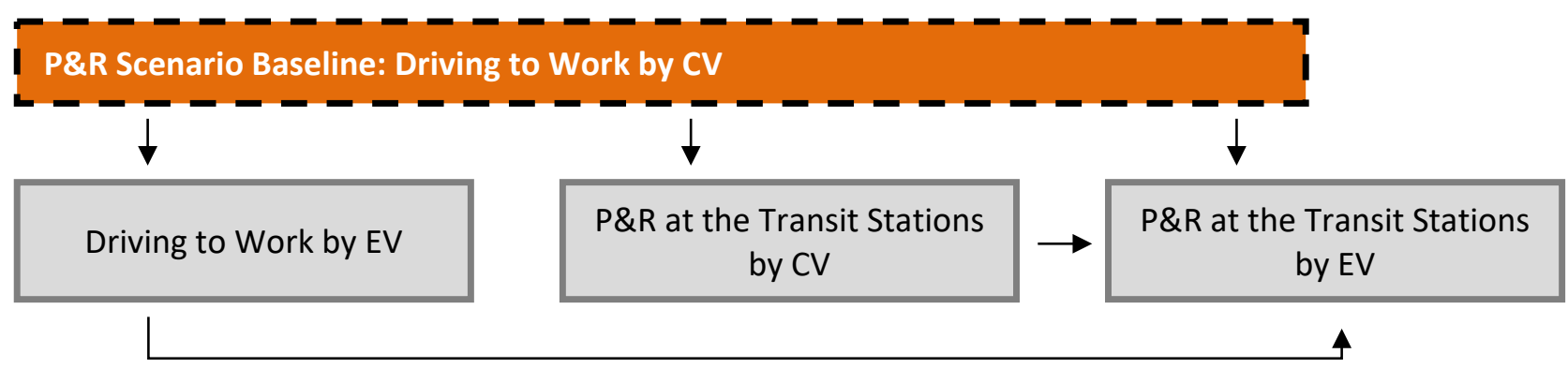

\section{ABT Scenario Baseline: Driving to Work and Shop by CV}

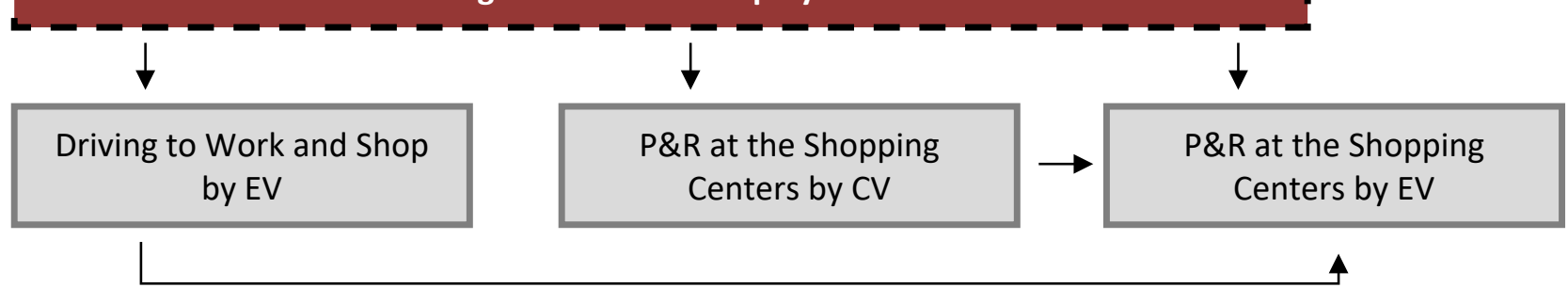

It is worth noting that the regional impacts of VMT and emission reductions should not be solely based on the planned number of EV charging outlets. The impacts will be broader due to the parking turnover at public sites. So the anticipated impacts of travel behavior changes may present different impacts at the individual and societal levels. In addition, there can be trade-offs among different categories of costs and benefits, as summarized in Table 4. For example, although changing from drive-to-work to P\&R using an EV may decrease an individual's EV charging cost and contribute social benefits, individual commuters' travel time that involves multiple modes tends to be more than driving-alone trips. 
Table 4 Anticipated Impacts of EV-Transit Integrated System Design

\begin{tabular}{|c|c|c|c|c|c|c|}
\hline \multirow{2}{*}{ Scenarios } & \multicolumn{2}{|c|}{ Economic Impacts } & \multicolumn{2}{|c|}{ Environment Impacts } & \multicolumn{2}{|c|}{ Challenges } \\
\hline & Individual & Society & Individual & Society & Individual & Society \\
\hline $\begin{array}{l}\text { P\&R } \\
\text { Scenario }\end{array}$ & $\begin{array}{l}\text { Decreases in } \\
\text { demand for EV } \\
\text { charging - cost } \\
\text { savings. } \\
\text { Increases in the } \\
\text { parking costs. }\end{array}$ & $\begin{array}{l}\text { Reduction in } \\
\text { congestion costs. } \\
\text { Improved } \\
\text { efficiency of } \\
\text { transit services. }\end{array}$ & $\begin{array}{l}\text { Driving-alone } \\
\text { VMT reduction } \\
\text { Short distance of } \\
\text { daily travel } \\
\text { encourages the } \\
\text { EV adoption. }\end{array}$ & $\begin{array}{l}\text { Fewer cars on } \\
\text { road; less } \\
\text { congestion. } \\
\text { Emission } \\
\text { Reduction. } \\
\text { Emission } \\
\text { reduction } \\
\text { through fuel } \\
\text { economy. }\end{array}$ & $\begin{array}{l}\text { Individual } \\
\text { commuting time } \\
\text { may increase } \\
\text { compared to } \\
\text { driving to work } \\
\text { scenario. }\end{array}$ & $\begin{array}{l}\text { Competition for } \\
\text { limited P\&R } \\
\text { space. }\end{array}$ \\
\hline $\begin{array}{l}\text { ABT } \\
\text { Scenario }\end{array}$ & $\begin{array}{l}\text { Decreases in } \\
\text { demand for EV } \\
\text { charging - cost } \\
\text { savings. }\end{array}$ & $\begin{array}{l}\text { Increases in sales } \\
\text { revenue at EV- } \\
\text { supportive } \\
\text { shopping center. } \\
\text { Improved } \\
\text { utilization rate at } \\
\text { commercial sites } \\
\text { and relieve space } \\
\text { constraints at } \\
\text { P\&R. }\end{array}$ & $\begin{array}{l}\text { VMT reduction } \\
\text { Emission } \\
\text { reduction }\end{array}$ & $\begin{array}{l}\text { Emission } \\
\text { reduction } \\
\text { through fuel } \\
\text { economy and } \\
\text { VMT reduction. }\end{array}$ & $\begin{array}{l}\text { Uncertainties in } \\
\text { parking } \\
\text { location/space } \\
\text { on non-ABT } \\
\text { trips/workdays. }\end{array}$ & $\begin{array}{l}\text { Shuttle service or } \\
\text { bike programs } \\
\text { may be needed } \\
\text { to transport } \\
\text { commuters from } \\
\text { shopping centers } \\
\text { to transit } \\
\text { stations. }\end{array}$ \\
\hline
\end{tabular}




\section{CASE IMPLEMENTATION IN CHICAGO}

The goal of this case study is to provide scenario-based data references for implementing the planning framework as discussed Section 4. The boundary of the study area is defined as the sevencounty area within the Chicago Metropolitan Agency for Planning (CMAP) region, which includes Cook, DuPage, Kane, Kendall, Lake, McHenry, and Will Counties.

The Chicago metropolitan region was chosen for our case illustration because of its large EV market potential and well-developed public transit system. The vehicle registration records of the state of Illinois indicate there are 4,800 PEVs and 161,200 HEVs within the state in 2015. The seven-county study area contains $74.7 \%$ of the EVs in the state. The 2014 American Community Survey (ACS) shows 9.5 million residents within in the study region. For the purpose of our study, we focused on commuters in suburban areas where transit services are limited and driving-alone VMT tend to be long.

Section 5.1 starts with an inventory analysis and background review of the commuting patterns, commuter rail services, EV market and charging infrastructure in Chicago. Section 5.2 discusses the strategies that we have developed to prepare the data for calculating the SI of siting the EV charging station. Sections 5.3 and 5.4 present the results of our recommended METRA P\&R sites and alternative sites (i.e., shopping centers in proximity to METRA stations), respectively, for EV charging. Section 5.5 quantifies the environmental impact of anticipated travel behavior changes given the integrated EVTransit design.

\subsection{Background Review and Inventory Analysis}

\subsubsection{Commuting Patterns in Chicago}

According to the CMAP's travel survey, eight out of ten commuters drive alone to work (CMAP 2008, Frank 2010). The average trip distance for those who drive alone is 9.67 miles (Table 5). The second ranked mode is commuter rail, which services $5 \%$ of the survey's commuters. The average trip distance for rail commuters is significantly longer, at over 22 miles.

\subsubsection{Commuter Rail Infrastructure}

The large share of rail commuters among public transit users may be attributed to the welldeveloped rail system in the region. The regional commuter rail agency, METRA, manages 11 lines that radiate out from Chicago's Loop and serves more than 100 communities with 241 rail stations. In 2015, METRA serviced nearly 81.6 million passenger trips with an average travel distance of 21.89 miles per passenger (METRA 2016).

This study retrieved METRA station-level data from the Regional Transportation Authority Mapping and Statistics (RTAMS) and summarized the station statistics in Table 6. The seventy five stations that are located within the City of Chicago boundary were excluded. Among 166 stations included in this study, a majority (164) have P\&R facilities, although their capacity and utilization vary greatly. The number of parking spots ranges from 2 to 4,245. Eighteen stations have reached their P\&R capacity; i.e., the parking utilization rate equals 1 . In addition, forty three stations have a parking 
utilization rate larger than 0.95 . This suggests that not all METRA P\&R sites are feasible to accommodate EV chargers, unless parking policies are revised to prioritize EV drivers. Understandably, ridership by station also varies. On average, 750 passengers get on board at a METRA station on a weekday; the busiest station services nearly 6,000 passenger trips. Three quarters of METRA riders use a car to get to the train station (Table 6).

Table 5 Regional Commuting Trip Characteristics

\begin{tabular}{lccc}
\hline & Survey Sample Size & Percent of Workers & $\begin{array}{c}\text { Average Distance to } \\
\text { Work (Miles) }\end{array}$ \\
\hline Drive Alone & 8,465 & $76.34 \%$ & 9.67 \\
Carpool & 177 & $1.60 \%$ & 7.54 \\
Taxi & 19 & $0.17 \%$ & 5.36 \\
Bus & 302 & $2.72 \%$ & 5.20 \\
Transit Rail & 331 & $2.98 \%$ & 7.72 \\
Regional Rail & 555 & $5.00 \%$ & 22.57 \\
Walk & 417 & $3.76 \%$ & 0.66 \\
Bike & 119 & $1.07 \%$ & 3.17 \\
More Than One & 192 & $1.73 \%$ & \\
Mode & 512 & $4.62 \%$ & 9.69 \\
Other & 11,089 & $100 \%$ & \\
\hline \multicolumn{4}{l}{ Total } \\
\hline
\end{tabular}

Source: Chicago Regional Household Travel Inventory 2008

Table 6 METRA Station Summary Statistics

\begin{tabular}{lcccc}
\hline & Mean & $\begin{array}{c}\text { Standard } \\
\text { Deviation }\end{array}$ & Minimum & Maximum \\
\hline $\begin{array}{l}\text { Ridership } \\
\text { Weekday Boarding }\end{array}$ & 749.7 & 737.3 & 27 & 5874 \\
$\begin{array}{l}\text { Parking } \\
\quad \text { Parking Capacity }\end{array}$ & 513.0 & 503.1 & 0 & 4245 \\
$\quad$ Parking Utilization & 0.713 & 0.271 & 0 & 1 \\
$\begin{array}{l}\text { Mode to station } \\
\quad \text { Drive Alone }\end{array}$ & 0.541 & 0.184 & 0.03 & 1 \\
$\quad$ Drop Off \& Car & 0.207 & 0.070 & 0 & 0.45 \\
$\begin{array}{l}\text { Pool } \\
\quad \text { Walk \& Bike }\end{array}$ & 0.225 & 0.190 & 0 & 0.93 \\
$\quad$ Other & 0.027 & 0.052 & 0 & 0.42 \\
\hline $\begin{array}{l}\text { Source: } R \text { RTAMS data sets on METRA Parking Capacity and Utilization Counts, } \\
\text { On-Board Survey and Mode of Access by Station Tabulation in 2014. }\end{array}$
\end{tabular}




\subsubsection{EV Charging Infrastructure and Existing Market}

There are $279 \mathrm{EV}$ charging stations currently located in the Chicago region. Figure 6 illustrates the geographic distribution of existing infrastructure. Existing EV charging stations mostly cluster along highways to enable long distance travel. Only $23 \mathrm{EV}$ charging stations in our study area are within a quarter mile of the Metra stations (shown in red in Figure 6); EV charging is available at five stations (out of 166 stations in the study area), and those chargers were installed by different private companies. It suggests that there is limited integration of EV charging with the METRA system from a central planning perspective.

There are 4,800 PEVs in the state of Illinois and the CMAP region, or our study region, has 3,900 PEVs, which account for more than $80 \%$ of PEVs in the state. Figure 7 illustrates the spatial distribution by EV volume (i.e., number of EVs by zip code). There seem to be four clusters of current EVs ownership: the Loop area, the lakefront of Lake and Cook Counties (e.g., Deerfield, Highland Park, Northbrook, and Winnetka), the northwest to the City of Chicago (Barrington), and the DuPage County (Hinsdale). Because the area of Chicago zip code varies greatly, Figure 8 was created to present the EV density (i.e., number of EVs per square mile). Clusters of EV ownership are highlighted in the riverfront area from the Loop to the Highland Park. Neighborhoods to the west of Chicago (e.g. West Town, Oak Park and Hinsdale) also show high EV density. All these communities have the higher median high household income compared to other neighborhoods in the region. In addition, these communities have at least one Metra station that provides services for more than 1,000 people per weekday, which shows the potential of implementing the EV-transit integrated approaches. 
Figure $6 \mathrm{EV}$ Charging and METRA Stations

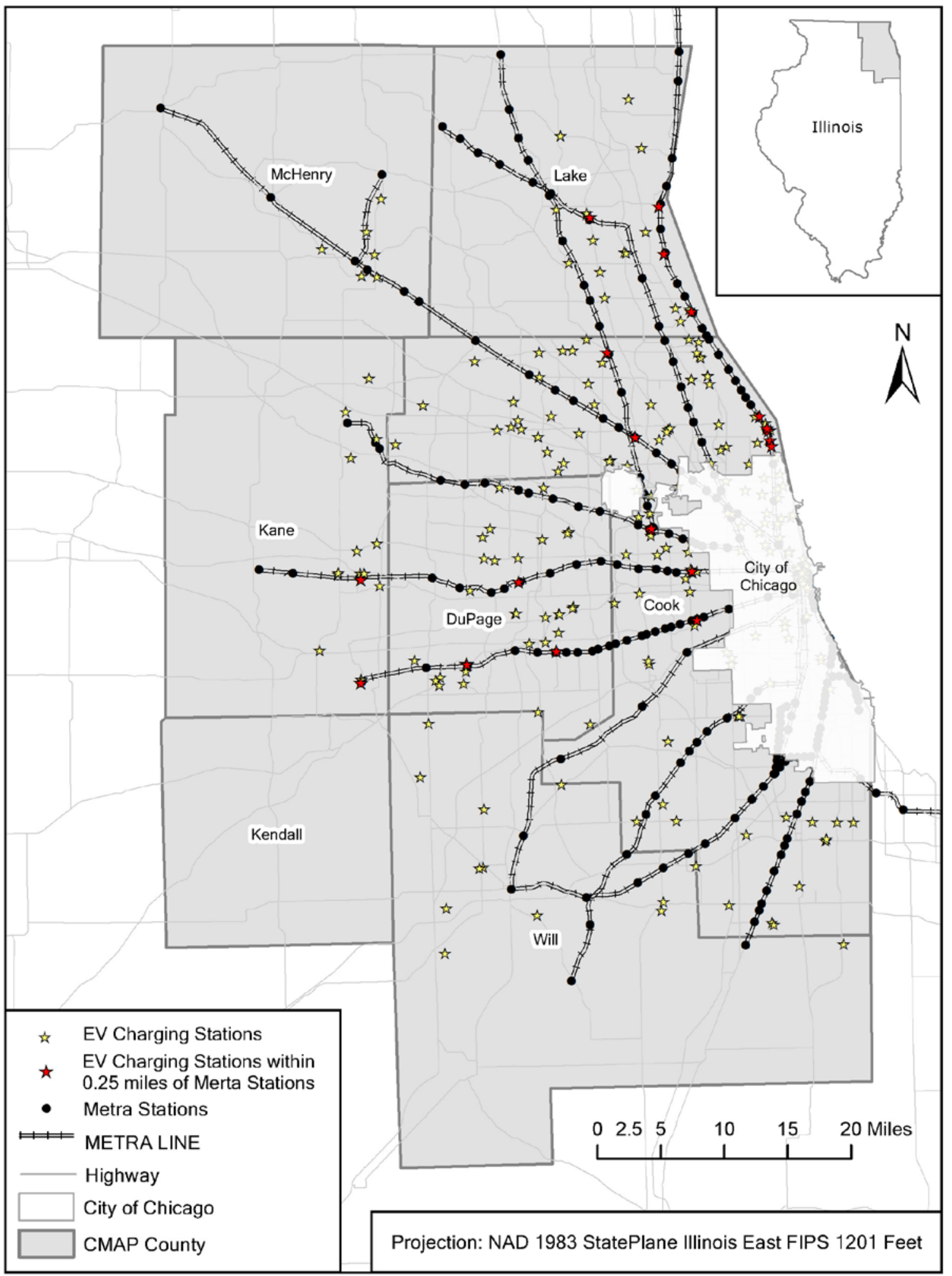

Map by Author. Data sources: METRA-Station from City of Chicago data portal; EV charging station from Alternative Fuels Data Center, U.S. Department of Energy. 
Figure 7 EV Charging Stations vs. EV Ownership by ZIP Code in Chicago Metro

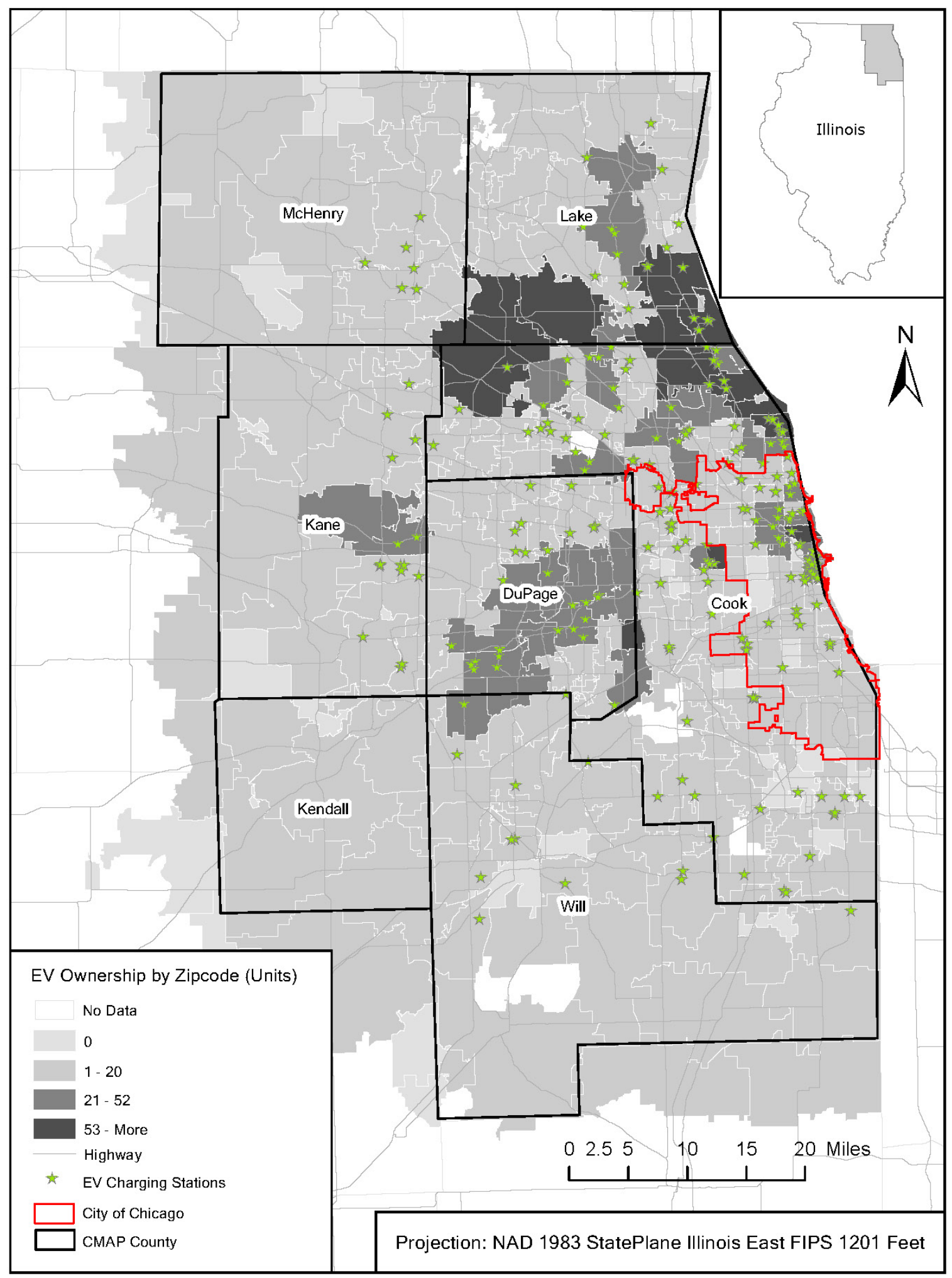

Map by Author. Source: Vehicle Registration Data, obtained from via FOIA; EV charging stations, Alternative Fuels Data Center, U.S. Department of Energy. 
Figure 8 EV Charging vs. EV Ownership Density

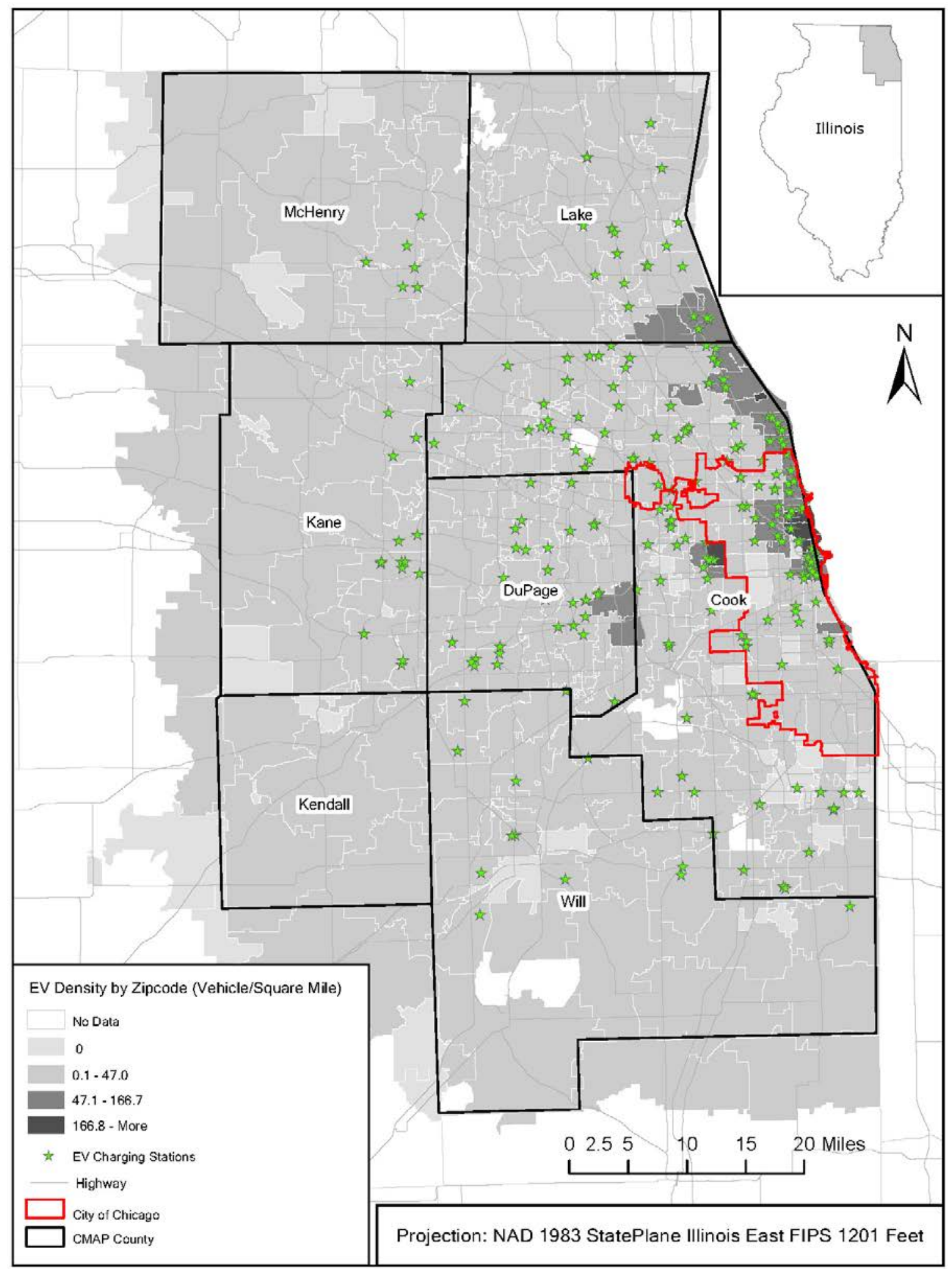

Map by Author. Source: Vehicle Registration Data, obtained from via FOIA; EV charging stations, Alternative Fuels Data Center; ZIP Code Land Area, U.S. Census Bureau. 


\subsection{Data Preparation}

As discussed in Section 4, in order to calculate the SI of siting EV charging at METRA stations, at least four factors need to be measured and quantified: (1) existing demand of EV charging; (2) potential demand of EV charging; (3) feasibility of siting EV charging stations at a METRA P\&R; and (4) feasibility of siting EV charging stations at alternative sites connected with METRA stations (in terms of the distance between METRA and alternative parking sites, or shopping centers in our ABT scenario).

For the purpose of this study, we chose the individual METRA station as the unit of analysis in the P\&R scenario, and shopping centers in the ABT scenario. For existing EV ownership, we calculated the average density of EV ownership in the zip code areas within five miles of each Metra station. For potential EV ownership, we referred to the results of SimmonsLOCAL consumer survey (Fall 2013) that asks respondents' the likelihood of their purchasing a new vehicle in next 3 years. For the number of commuters who drive EV from home to METRA stations, we retrieved METRA riders' information from RTAMS about weekday ridership and riders' travel mode split for trips between home and train stations. Annual population growth rate in surrounding communities was considered as a factor to estimate potential demand. The summary statistics about existing and potential demand of EV charging are presented in Table 7. The demand factors were standardized in the procedures as described in Section 4.3.

Table 7 Descriptive Statistics of Demand Factors

\begin{tabular}{lrrrr}
\hline & Mean & $\begin{array}{r}\text { Standard } \\
\text { Deviation }\end{array}$ & Minimum & Maximum \\
\hline $\begin{array}{l}\text { Existing Demand } \\
\quad \text { EV Density (Vehicle/Square Mile) }\end{array}$ & 36.52 & 107.16 & 0 & 1,113 \\
$\quad$ P\&R Ridership & 414.99 & 471.61 & 3 & 4,229 \\
$\quad \begin{array}{l}\text { Potential Demand } \\
\quad \text { Future Vehicle Purchase (Vehicle }\end{array}$ & 23,533 & 28,543 & 0 & 179,747 \\
$\quad$ /Square Mile) & & & & \\
$\quad$ Population Growth & $0.72 \%$ & 0.0186 & $-0.34 \%$ & $14.81 \%$ \\
\hline
\end{tabular}

Sources: Vehicle Registration Data, obtained from the State of Illinois via FOIA; Weekday ridership, Mode to Station, RTAMS; Future Vehicle Purchase, SimmonsLOCAL Fall 2013 full year consumer survey; ZIP Code Land Area and Population Change, U.S. Census Bureau.

To determine the feasibility of siting EV charging stations at METRA stations, we evaluated the station's P\&R capacity and utilization rates based on the parking survey results from the RTAMS database. Installing EV chargers at these stations and specifying reserved spots for EVs may further increase the competition for the parking availability. For an early-stage implementation before EV further penetrates the market, fully and close-to-fully utilized $P \& R$ facilities were filtered. The number of underutilized spots were derived from multiplying the underutilization rate by the total parking capacity (No. of spots). The threshold of 100 was determined by analyzing the histogram of existing P\&R capacity and utilization rates. If the station has fewer than 100 underutilized parking spots, it was coded as Not-Feasible; otherwise Feasible. Among 166 stations in this study, 62 stations were found to be potentially Feasible. 
Besides METRA P\&R stations, we explored alternative sites, which can support the ABT scenario as discussed in Section 4. In this study, we focused on suburban shopping centers, which often have many unoccupied parking spaces during daytime on weekdays. The major shopping center database, compiled in the Directory of Major Malls, contains the shopping centers with gross leasable area larger than 100,000 sq. $\mathrm{ft}$. and other lifestyle/specialty centers (DMM 2015). We identified the shopping centers within two miles of the closest METRA station and ranked them by their distance to the closest station.

\subsection{Results of Top Recommended Location for EV Charging: P\&R Scenario}

Based on the SI ranking among all feasible stations (i.e., with over 100 parking spots available), the top 10 desirable stations for siting EV chargers were listed in Table 8 and mapped in Figure 9. Five of the desirable stations cluster in northern Cook County, four stations spread out to the west of the region, and one station is in the south, close to the border of Cook and Will Counties. While it does not appear to be an even distribution, it confirms to the patterns of EV market and ownership. Two of the 10 selected locations, one in Aurora and one in Wheeling, are already equipped with EV charging. This study suggested eight new locations, which can be potentially efficient and effective in promoting both EV adoption and METRA rides.

Table 8 Top 10 Desirable P\&R Location

\begin{tabular}{cllll}
\hline Rank & Station Name & Station ID & Station Address & City \\
\hline 1 & North Glenview & 51215188 & 3000 Old Willow Rd. & Glenview \\
2 & Lake Cook & 51215230 & 601 Lake Cook Road & Deerfield \\
3 & Arlington Heights & 51213228 & 19 E. Northwest Highway & Arlington Heights \\
4 & Wheaton & 51211250 & 402 Front St. (at West St.) & Wheaton \\
5 & Prospect Heights & 51216240 & 55 South Wolf Road & Prospect Heights \\
6 & Aurora & 51210380 & 233 N. Broadway & Aurora \\
7 & Elmhurst & 51211157 & 128 W. 1st St. (at York Rd.) & Elmhurst \\
8 & Wheeling & 51216272 & 400 Town Street & Wheeling \\
9 & 80th Ave. & 51206251 & 18001 S. 80th Ave. & Tinley Park \\
10 & Schaumburg & 51212265 & 2000 S. Springinsguth Rd. & Schaumburg \\
\hline
\end{tabular}


Figure 9 Top 10 Recommended EV Charging Location at METRA P\&R

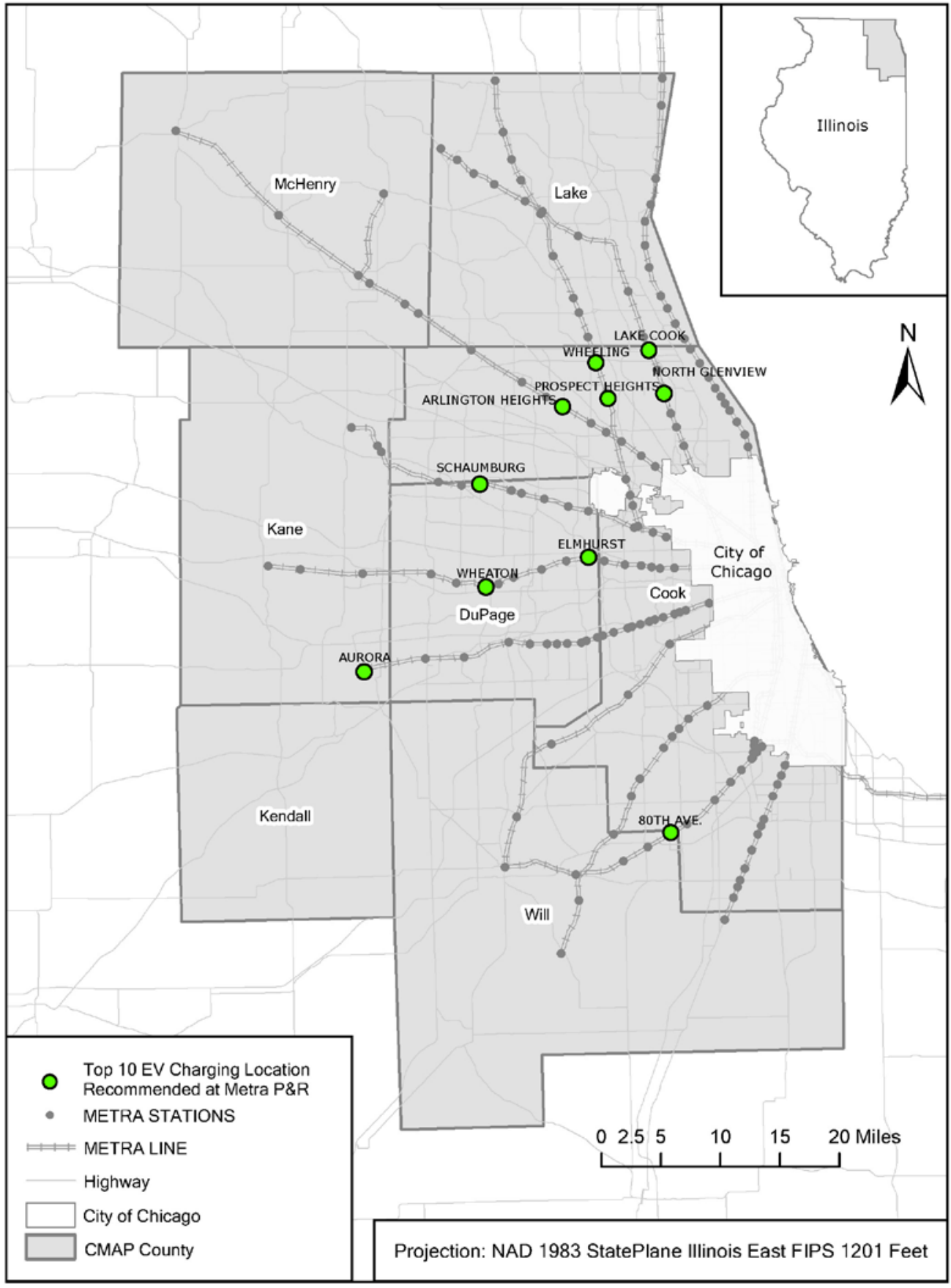




\subsection{Results of Top Recommended Location for EV Charging: ABT Scenario}

For the ABT scenario, we investigated the location of all suburban shopping centers in terms of its distance to the closest METRA stations. While there are many shopping centers within two miles of the closest station, only a few are within walking distance (marked in green in Figure 10). This suggests limited opportunities for off-site EV charging in connection with METRA stations. In most cases, siting EV charging at commercial centers may require an additional mode of transportation, such as by bike or shuttle.

Selected shopping centers that are desirable for installing EV charging under the ABT scenario are listed in Table 9 and mapped in Figure 11. Ten shipping centers nearby four METRA stations have been selected; all are located in the northern Cook County. None of these shopping centers have EV charging facilities at present.

Table 9 List of Desirable Shopping Centers

\begin{tabular}{|c|c|c|c|c|c|}
\hline Rank & Shopping Center & Address & City & Station Name & $\begin{array}{c}\text { Distance to } \\
\text { Nearest Station }\end{array}$ \\
\hline 1 & $\begin{array}{l}\text { The Glen Town } \\
\text { Center }\end{array}$ & $\begin{array}{l}\text { West Lake Ave. \& } \\
\text { Patriot Blvd. }\end{array}$ & Glenview & $\begin{array}{l}\text { North } \\
\text { Glenview }\end{array}$ & 0.71 \\
\hline 2 & Prairie View Plaza & $\begin{array}{l}\text { SEC Dempster St. \& } \\
\text { Waukegan Ave. }\end{array}$ & $\begin{array}{l}\text { Morton } \\
\text { Grove }\end{array}$ & Morton Grove & 0.66 \\
\hline 3 & Deerbrook Mall & $\begin{array}{l}\text { SWC Lake Cook \& } \\
\text { Waukegan Rd. }\end{array}$ & Deerfield & $\begin{array}{l}\text { Lake Cook } \\
\text { Road }\end{array}$ & 0.30 \\
\hline 4 & Willow Festival & $\begin{array}{l}\text { Willow Rd \& } 3 \text { Lakes } \\
\text { Dr. }\end{array}$ & Northbrook & $\begin{array}{l}\text { North } \\
\text { Glenview }\end{array}$ & 0.91 \\
\hline 5 & $\begin{array}{l}\text { Church Street } \\
\text { Plaza }\end{array}$ & $\begin{array}{l}\text { Church St. \& Maple } \\
\text { Ave. }\end{array}$ & Evanston & Davis St. & 0.08 \\
\hline 6 & Sherman Plaza & $\begin{array}{l}\text { Sherman Ave. \& } \\
\text { Davis St. }\end{array}$ & Evanston & Davis St. & 0.11 \\
\hline 7 & Civic Center Plaza & $\begin{array}{l}\text { SEC Oakton St. \& } \\
\text { Waukegan Rd. }\end{array}$ & Niles & Morton Grove & 1.06 \\
\hline 8 & $\begin{array}{l}\text { Mount Prospect } \\
\text { Plaza }\end{array}$ & $\begin{array}{l}\text { NWC Rand \& Central } \\
\text { Rds. }\end{array}$ & $\begin{array}{l}\text { Mount } \\
\text { Prospect }\end{array}$ & $\begin{array}{l}\text { Mount } \\
\text { Prospect }\end{array}$ & 0.93 \\
\hline 9 & Northbrook Court & $\begin{array}{l}\text { Lake Cook Rd. \& } \\
\text { Northbrook Ct. }\end{array}$ & Northbrook & $\begin{array}{l}\text { Lake Cook } \\
\text { Road }\end{array}$ & 1.24 \\
\hline 10 & Pointe Plaza & $\begin{array}{l}\text { Touhy Ave. \& Central } \\
\text { Ave. }\end{array}$ & Niles & Morton Grove & 1.69 \\
\hline
\end{tabular}


Figure 10 Commercial Centers as Potential Off-Site P\&R near METRA Stations

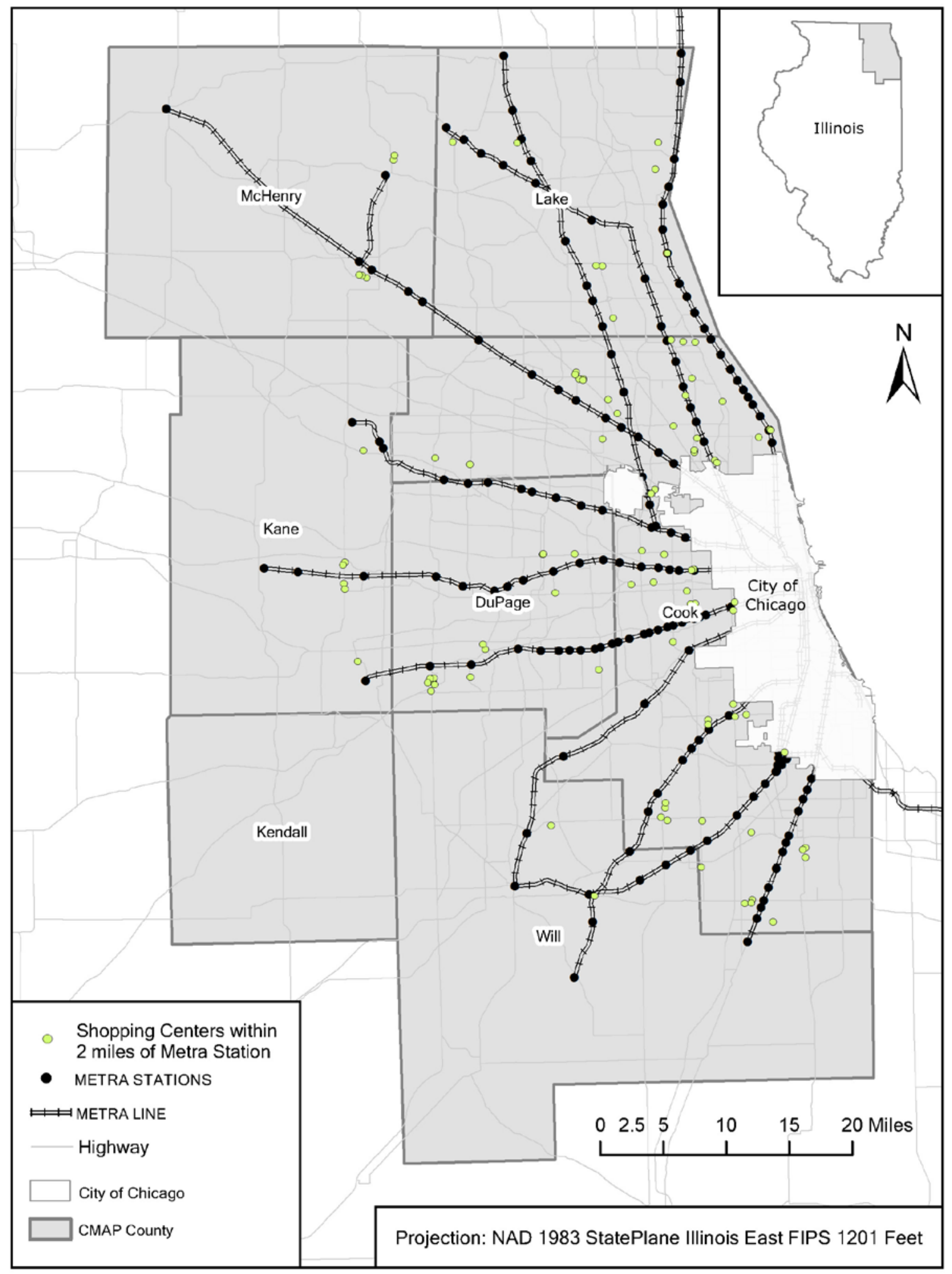

Map by Author. Data source: Directory of Major Malls, Inc., Business Analyst 2015 dataset, ESRI. 
Figure 11 Top 10 Recommended EV Charging Location at Shopping Center

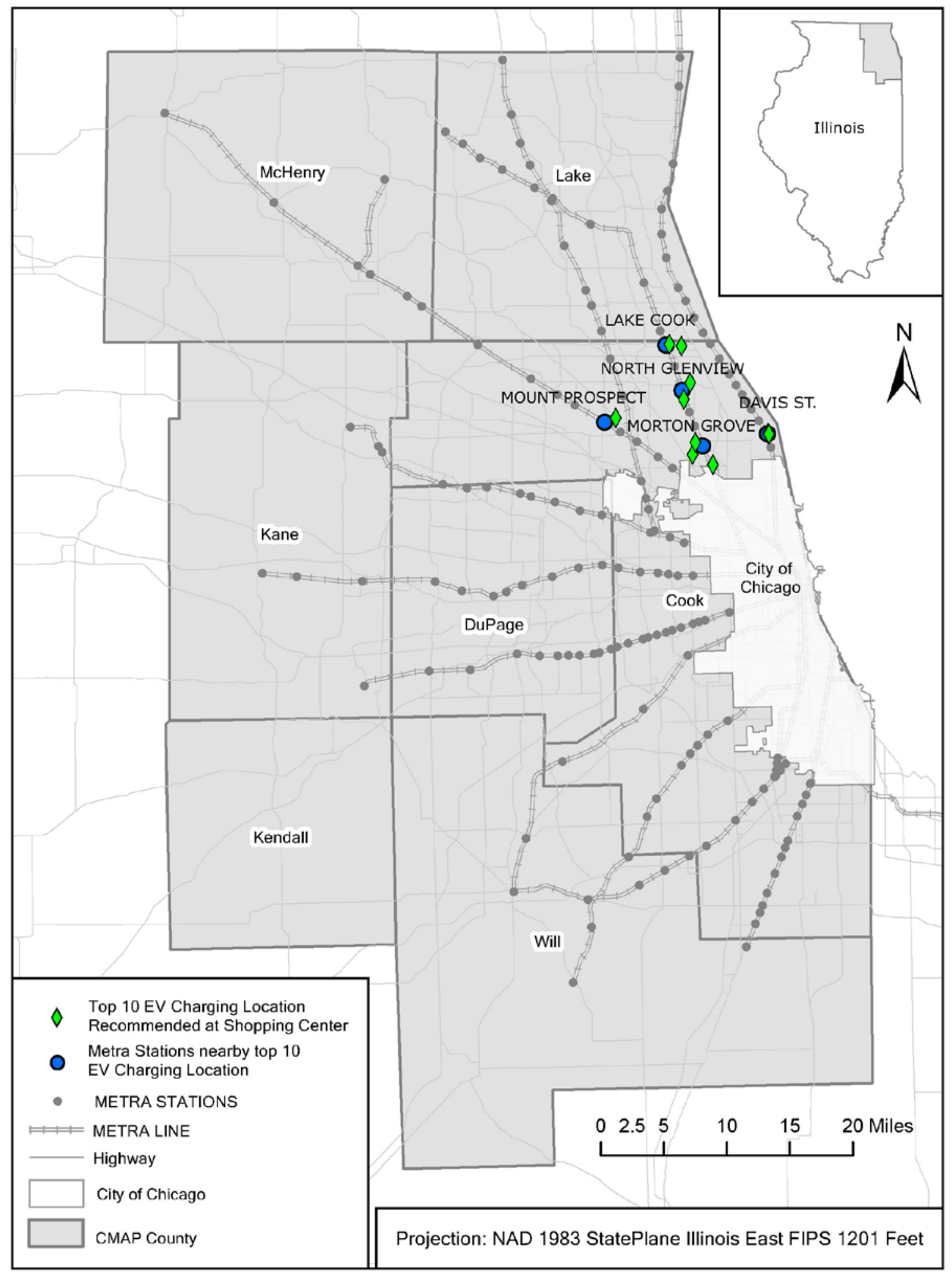




\subsection{Environmental Impacts}

As a metric to quantify the impacts of anticipated traveler behavior changes, carbon emissions of various travel modes on the trip-chain basis were calculated following Equation (3).

$$
\text { Total Emission }_{i j}=\sum \text { Distance }_{i j} \times \text { Emission Factor }_{i j} \times \text { Frequency }_{i j}
$$

Where,

$$
\begin{aligned}
& i=\text { Type of vehicle } \\
& j=\text { Trip segments }
\end{aligned}
$$

Distance $=$ Trip distance of a specific vehicle at a specific trip segment

Emission Factor = Carbon emissions factor of a specific vehicle at a specific trip segment, $\mathrm{Kg} / \mathrm{Mile}$

Frequency = Trip frequency of a specific vehicle at a specific trip segment

In this study, emission factors for conventional vehicle and commuter rail (Table 10) were adopted from the U.S. EPA estimates (U.S. EPA 2015). For EVs, recent research suggests a wide range (Table 11) depending on model types and regional electricity portfolio (Hula, Bunker, and Alson 2015). For example, the BEV emission factor ranges from $40 \mathrm{~g} / \mathrm{mile}$ to $229 \mathrm{~g} / \mathrm{mile}$, and the emission factor for PHEV ranges from $212 \mathrm{~g} / \mathrm{mile}$ to $315 \mathrm{~g} / \mathrm{mile}$. Accordingly, an average value of $180 \mathrm{~g} / \mathrm{mile}$ was adopted in this study.

Table 10 Emission Factors Suggested by EPA, 2015 (Kg/Mile)

\begin{tabular}{ccc}
\hline Type & $\mathrm{CO}_{2}$ factor & Unit \\
\hline $\begin{array}{c}\text { Passenger Car } \\
\text { Conventional }\end{array}$ & 0.355 & Vehicle-mile \\
Vehicles & 0.180 & Vehicle-mile \\
Electric Vehicles & 0.169 & Passenger-mile \\
Commuter Rail &
\end{tabular}

Source: GHG Emission Factors Hub, U.S. Environmental Protection Agency, 2015.

Table 11 Emission Factors of EVs (Tailpipe \& Net Upstream $\mathrm{CO}_{2}, \mathrm{Kg} / \mathrm{Mile}$ )

\begin{tabular}{lrrr}
\hline & Low & Average & High \\
\hline $\begin{array}{l}\text { Battery EV } \\
\begin{array}{l}\text { Plug-in } \\
\text { Hybrid EV }\end{array}\end{array}$ & 0.040 & 0.124 & 0.229 \\
\hline \multicolumn{1}{c}{ All EVs } & 0.212 & 0.257 & 0.315 \\
\hline
\end{tabular}

Source: Light-Duty Automotive Technology,

Carbon Dioxide Emissions, and Fuel Economy

Trends: 1975 through 2015, U.S. Environmental

Protection Agency, 2015 
As shown in Equation (3), besides the emission factor, travel distance and frequency are also critical factors. Both of these factors may change given the integrated EV-Transit design, as discussed in Table 3 and Table 4. The average travel distances were extracted from CMAP's household travel survey. Suburban P\&R riders in Chicago, on average, traveled 28 miles to work, which is $15 \%$ more than average METRA riders (24 miles). This number aligns with studies in other regions, where commuters' driving distances to/from commuter rail stations ranges from 2.5 to 5 miles (Duncan and Cook 2014, Foote 2000, Kim, Ulfarsson, and Hennessy 2007, Stieffenhofer, Barton, and Gayah 2015, Turnbull, Pratt, and Evans 2004). For the ABT scenario, data for travel distance and frequency for various trip purposes were obtained from the CMAP survey (Table 13). The average trip distance is 20.3 miles and 10.7 miles for separate work and shopping trip chain. When combined, the total travel distance is reduced to 25.6 miles or $83 \%$ of separated trip chains (Frank 2010).

Table 12 Mode to Station in Suburban Chicago

\begin{tabular}{|c|c|c|c|}
\hline & $\begin{array}{c}\text { Survey } \\
\text { Sample Size }\end{array}$ & $\begin{array}{l}\text { Percent of } \\
\text { Workers }\end{array}$ & $\begin{array}{l}\text { Average Distance to } \\
\text { Work (Miles) }\end{array}$ \\
\hline Drive Alone & 214 & $55.73 \%$ & 28.18 \\
\hline Drop Off & 50 & $13.02 \%$ & 26.66 \\
\hline Walk \& Bike & 123 & $32.03 \%$ & 18.27 \\
\hline Total & 387 & $100 \%$ & 24.81 \\
\hline
\end{tabular}

Source: Chicago Regional Household Travel Inventory 2008

Table 13 Work Trip Chain vs. Work Shopping Chain

\begin{tabular}{lcrrrr} 
& Work & Shop & $\begin{array}{c}\text { Work with } \\
\text { Shop }\end{array}$ & Other & All \\
\hline $\begin{array}{l}\text { Mileage Per Trip } \\
\text { Chain }\end{array}$ & 20.3 & 10.7 & 25.6 & 9.1 & 13.7 \\
\hline
\end{tabular}

Source: Mode Choice and Trip Purpose for the 2008 and 1990 Surveys, CMAP 2010

Table 14 shows the results of estimated carbon emission and VMT reductions by applying the average travel distance of commuters in the Chicago region. On average, a commuter can reduce up to $85 \%$ VMT and $45 \%$ carbon emissions by shifting from driving-alone in a CV to combined EV-transit use. Existing P\&R riders, when driving an EV, may reduce carbon emissions by $8 \%$ compared to driving a CV. Although the carbon emission reductions from driving an EV to work and P\&R using a EV appear to be at the same level (49\% and 45\%), P\&R using EVs could reduce 85\% driving-alone VMT on average; that is, contributing to fewer vehicles on road.

In the ABT scenario, at the maximum, $P \& R$ at shopping centers using EVs can reduce carbon emissions by $52 \%$ and VMT by $85 \%$ compared to the baseline scenario of driving to work and shopping in a CV. The P\&R is competitive to driving alone using a EV in both carbon emissions and VMT 
reduction. Applying the average distance for work-shop trip chains, it could possibly reduce $4.73 \mathrm{~kg}$ carbon emissions and 22.27 VMT per commuter-day.

Table 14 Environmental Impact of Anticipated Changes in Travel Behavior

\begin{tabular}{|c|c|c|c|c|c|c|}
\hline & \multicolumn{3}{|c|}{ GHG Emission } & \multicolumn{3}{|c|}{ Vehicle Miles Traveled } \\
\hline & Factor & $\begin{array}{r}\text { Reduction } \\
\text { (Pct) }\end{array}$ & $\begin{array}{r}\text { Reduction } \\
\text { (Kg) }\end{array}$ & Factor & $\begin{array}{r}\text { Reduction } \\
\text { (Pct) }\end{array}$ & $\begin{array}{r}\text { Reduction } \\
\text { (VMT) }\end{array}$ \\
\hline \multicolumn{7}{|l|}{$P \& R$ scenario } \\
\hline Driving to work by CV & 1.00 & B.L. & 0.00 & 1.00 & B.L. & 0.00 \\
\hline Driving to work by EV & 0.51 & $49 \%$ & 3.53 & 1.00 & $0 \%$ & 0.00 \\
\hline $\mathrm{P} \& \mathrm{R}$ at the transit stations by $\mathrm{CV}$ & 0.63 & $37 \%$ & 2.67 & 0.15 & $85 \%$ & 17.26 \\
\hline$P \& R$ at the transit stations by EV & 0.55 & $45 \%$ & 3.24 & 0.15 & $85 \%$ & 17.26 \\
\hline \multicolumn{7}{|l|}{ ATB scenario } \\
\hline Driving to work and shops by CV & 1.00 & -- & 0.00 & 1.00 & -- & 0.00 \\
\hline Driving to work and shops by EV & 0.51 & $49 \%$ & 4.45 & 1.00 & $0 \%$ & 0.00 \\
\hline $\begin{array}{l}\text { P\&R at the shopping centers by } \\
C V\end{array}$ & 0.54 & $46 \%$ & 4.18 & 0.13 & $85 \%$ & 22.27 \\
\hline $\begin{array}{l}\text { P\&R at the shopping centers by } \\
\text { EV }\end{array}$ & 0.48 & $52 \%$ & 4.73 & 0.13 & $85 \%$ & 22.27 \\
\hline
\end{tabular}

Note: B.L. = Baseline 


\section{DISCUSSION AND CONCLUSION}

\subsection{Need of Public Policy Support}

EV market penetration is anticipated to continue to grow rapidly. Despite many emerging legislative and economic incentives for EV adoption and infrastructure development, there are no formal planning guidelines for selecting a location to install EV infrastructure. EV infrastructure development has been largely driven by such market factors as costs, electricity grid features, and interested parties' preference. Current EV programs that prioritize residential and workplace charging as the key locations for EV chargers create exclusivity and inefficiency in facility operation as well as barriers to further EV adoption. While it is advantageous to continuously promote investment from the private sector (including both businesses and households), a more active role for the public sector is needed.

Recently, a few regions (reviewed in Section 3) have initiated programs to place public EV charging stations or charging outlets at transit stations. Such programs are anticipated to provide EV drivers with convenient charging and to promote transit ridership at the same time. In addition, combining EV charging and daytime parking in proximity to transit stations can potentially overcome some of the logistical challenges of installing public charging, such as the charging time and utilization rate, which can complement commuters' schedules and travel routines. By facilitating the accessibility of both EV charging and transit stops, multi-modal trips that include EV driving and transit use contribute to VMT and emission reductions.

Such an integrated EV-transit design presents an example of how the public sector might promote EV adoption and transit ridership at the same time if strategic planning is undertaken. It does require a collaboration among various agencies and constituencies (e.g., transportation agencies, utilities, land use, business development, EV manufacturers, and EV drivers). Policy programs, such as cost incentives and permitting rules, should support integrated design that aims to promote system efficiency, social equity and welfare, and environmental benefits.

\subsection{Contribution of This Study}

While a couple of integrated EV-transit programs are already developing, we found that there is limited information about their system planning process or the system's performance. To address this gap in practice, we developed a generic planning model that is anticipated to be applicable for regional planning agencies, and in addition to a SI that integrates the characteristics of EV market and transit services in quantitative metrics. Data variables in the SI were designed to be commonly available from publicly accessible data sources. Therefore, a regional agency can easily adapt the geographic boundary of their data analysis to meet their specific planning needs.

Another innovative component of this study is the consideration of activity based trips (ABT), which involve multiple trip segments/purposes of commuting trips. The existing programs that supply EV charging at transit P\&R sites mostly target work-home trips only. Through an inventory analysis, we found that many P\&R sites are already fully or nearly fully utilized; there are clearly space constraints. Reserving EV charging spots at P\&R sites can further exacerbate crowding effects and discourage P\&R 
rides. In contrast, the parking lots at large shopping centers is typically underutilized when P\&R sites are occupied during weekdays. And ABT account for about $50 \%$ of commuting trips (McGuckin and Srinivasan 2005, O'Kelly 1983). Therefore, we advocate for the siting of EV charging at shopping centers close to transit stops, which can fit in a reasonable proportion of commuters' commuting schedule, alleviate the P\&R space constraints at transit stops, and provide convenient charging.

We also hope this report will contribute to the body of literature that regards the performance evaluation of integrated EV-transit program design, in terms of VMT and carbon emissions. To avoid "comparing apples to oranges," we developed a separate process for the P\&R and ABT scenarios, which differ by the baseline scenario, travel distance, and travel frequency. In our case implementation, we referred to the regional average and calculated the VMT and carbon emission reductions for a commuter's anticipated travel behavior changes as a result of the integrated EV-transit design. Such estimates can provide important references for public agencies to target specific travelers or travel patterns for a cost-effective program design.

\subsection{Modeling Results in Chicago}

We implemented our proposed planning process and SI in the Chicago metropolitan region, which is one of the fast growing EV markets in the U.S. and is serviced by extensive transit systems. While a few commuter rail (METRA) stations (five out of 166 stations in our study area) are equipped with EV charging, Chicago does not have a centrally planned approach for an integrated EV-transit programs, as has been developed in Los Angeles or Boston. Our study aims to provide policy insights and data references for integrated EV-transit infrastructure in the near future.

Employing the SI that we developed in Section 4, we derived the index values for each METRA station and recommended the top 10 desirable stations for EV charging installment. Two of our 10 recommended selected locations, one in Aurora and one in Wheeling, are already equipped with EV charging. Eight new locations (Figure 9) conform to the patterns of EV market and ownership and clusters in the north and south of the region. The SI was calculated for all shopping center in proximity (i.e., within two miles) of METRA stations. Ten shopping centers near four METRA stations in the northern Cook County have been selected. None of these shopping centers have EV charging facilities at present, which confirms there are opportunities for expanding EV charging infrastructure in connection with transit uses.

In terms of anticipated benefits from integrated EV-transit programs, we found that the P\&R and $A B T$ scenarios contribute to the reduction of VMT and associated carbon emissions in different ways. In the P\&R scenario, VMT is reduced by combining EV and transit, compared to the drive to/from work baseline. In the ABT scenario, VMT is reduced by combining multiple trip segments, compared to the baseline of making separate trips for work and shopping. As there are other factors than the VMT that can contribute to carbon emissions (Equation 3), the scale of emission impacts can differ from than that of VMT (Table 14).

In the P\&R scenario, we found that a commuter can, on average, reduce up to $85 \%$ VMT and $45 \%$ carbon emissions by shifting from driving alone in a conventional vehicle to combined EV-transit uses. Driving an EV to work and P\&R using an EV appear to achieve the same level of carbon reductions (49\% vs. 45\%). However, P\&R using an EV could reduce $85 \%$ of driving-alone VMT on average and contribute to fewer vehicles on road, and is, consequently, preferable. 
In the ABT scenario, at the maximum, P\&R at a shopping center using an EV can reduce carbon emissions by $52 \%$ and VMT by $85 \%$ compared to the baseline scenario of driving to work and shopping in a conventional vehicle. On average, a traveler could possibly reduce $4.73 \mathrm{~kg}$ carbon emissions and 22.27 VMT per commuter-day through work-shop trip chains.

\subsection{Limitations and Future Research}

This study focuses on promoting multi-modal trips that include EV driving and transit use to reduce VMT and emissions. Although multi-modal trips can generally reduce the need for long-distance driving and facilitates transit use, combining EV driving and transit use can involve many uncertainties in the temporal and spatial distribution of potential impacts. Table 4 provides some examples of the trade-offs of benefits at the individual versus the societal level. A system impact analysis is still needed. Basically, not all benefits may be justified in VMT and carbon emissions. For example, current EV's emission factors range from 124 to $257 \mathrm{~g} /$ mile depending on the technology (BEV or PHEV) with an average of 180. In comparison, the emission factor for commuter rail is $169 \mathrm{~g} /$ passenger-mile. With evolving EV technology, the emission factors for EVs could potentially be lower than commuter rail. If measured by carbon footprint, driving EVs could be preferable to riding regional rail. However, increasing use of EVs would increase the number of cars on the road and incur costs to the entire transportation system. In addition, emissions from electricity generation in support of EVs are not often included in GHG emission estimates. A centralized charging approach, as we recommend here, would potentially support the deployment of renewable energy power generation.

In terms of our suggested locations, some of the existing EV charging sites at METRA stations are, surprisingly, not on our top recommendation list. This could suggest that additional factors should be included in our suitability analysis, or that those stations might not be the most cost-effective locations. Due to proprietary market data limitations, we were not able to access details of EV charging facility data for a focus study. Case studies in future, when information becomes available, can help justify and refine the variable selection in the Suitability Index. In addition, expert opinions and stakeholder inputs may provide valuable information for weighting the variable selection in the Suitability Index. In other words, some communities may determine that a specific set of variables can be more important than others in the context of their community's needs. 


\section{REFERENCES}

Adrianzen, Diego, Kristin Darby, and Hannah McCallum. 2010. Electric Vehicle Infrastructure in Massachusetts. Anair, Don, and Amine Mahmassani. 2012. State of Charge: Electric Vehicles' Global Warming Emissions and Fuel-cost Savings across the United States. Union of Concerned Scientists.

Babaee, Samaneh, Ajay S Nagpure, and Joseph F DeCarolis. 2014. How Much Do Electric Drive Vehicles Matter to Future US Emissions? Environmental Science \& Technology 48 (3):1382-1390.

Balmin, Judith, Greg Bonett, and Megan Kirkeby. 2012. Increasing Electric Vehicle Charging Access in Multi-Unit Dwellings in Los Angeles.

Block, David, John Harrison, and Paul Brooker. 2015. Electric Vehicle Sales for 2014 and Future Projections. In Electric Vehicle Transportation Center. Florida Solar Energy Center.

Bradley, Thomas H, and Andrew A Frank. 2009. Design, Demonstrations and Sustainability Impact Assessments for Plug-In Hybrid Electric Vehicles. Renewable and Sustainable Energy Reviews 13 (1):115-128.

Brecher, Aviva. 2012. Transit Bus Applications of Lithium Ion Batteries: Progress and Prospects.

CALSTART. 2013. Best Practices For Workplace Charging: Employer EV Initiative - Supporting Solutions for Workplace Charging.

Chapin, DM, R Brodd, G Cowger, JM Decicco, GC Eads, R Espino, JM German, DL Greene, J Greenwald, and LL Hegedus. 2013. Transitions to Alternative Vehicles and Fuels. National Academies Press, Washington, DC.

CMAP. 2008. Chicago Regional Household Travel Inventory 2008. In Travel Tracker Survey, edited by Chicago Metropolitan Agency for Planning.

Curtin, Richard, Yevgeny Shrago, and Jamie Mikkelsen. 2009. Plug-in hybrid Electric Vehicles. In Transportation Research Institute. University of Michigan.

DMM. 2015. 2015 DMM Major Shopping Center Methodology. In Directory of Major Malls database, edited by Directory of Major Malls.

Duncan, Michael, and David Cook. 2014. Is the Provision of Park-and-Ride Facilities at Light Rail Stations An Effective Approach to reducing Vehicle Kilometers Traveled in a US Context? Transportation Research Part A: Policy and Practice 66:65-74.

Eberle, Dr Ulrich, and Dr Rittmar von Helmolt. 2010. Sustainable Transportation Based on Electric Vehicle Concepts: A Brief Overview. Energy \& Environmental Science 3 (6):689-699. doi: 10.1039/C001674H.

Egbue, Ona, and Suzanna Long. 2012. Barriers to Widespread Adoption of Electric Vehicles: An Analysis of Consumer Attitudes and Perceptions. Energy Policy 48:717-729. doi: 10.1016/j.enpol.2012.06.009.

EV Connect. 2011. Los Angeles Builds Out New Electric Vehicle Charging Stations at Key Transit Locations. http://www.evconnect.com/press-releases/los-angeles-builds-out-new-electric-vehicle-chargingstations-at-key-transit-locations/.

FHA. 2015. The Congestion Mitigation and Air Quality Improvement (CMAQ) Program - MAP21. NASEO Energy Policy Outlook Conference.

Foote, Peter. 2000. Chicago Transit Authority Weekday Park-and-Ride Users: Choice Market with Rid ership Growth Potential. Transportation Research Record: Journal of the Transportation Research Board (1735):158-168.

Frades, Matt. 2014. A Guide to the Lessons Learned from the Clean Cities Community Electric Vehicle Readiness Projects.

Francfort, Jim, and Richard Brion Bennett. 2015. Plug-in Electric Vehicle and Infrastructure Analysis.

Frank, Parry. 2010. Mode Choice and Trip Purpose for the 2008 and 1990 Surveys. In Chicago Regional Household Travel Inventory: Chicago Metropolitan Agency for Planning.

Giles, Carrie, Carrie Ryder, and Stephen Lommele. 2016. Workplace Charging: Charging Up University Campuses. NREL (National Renewable Energy Laboratory (NREL), Golden, CO (United States)).

Greene Sr, David L. 2015. Alternative Transportation Refueling Infrastructure in the US 2014.

Hebdrick, Thomas. 2014. Aurora Installs First Public EV Charging Stations. http://kdvr.com/2014/02/26/aurorainstalls-first-public-ev-charging-stations/. 
Hula, Aaron, Amy Bunker, and Jeff Alson. 2015. Light-Duty Automotive Technology, Carbon Dioxide Emissions, and Fuel Economy Trends: 1975 Through 2015. In Trends Report.

Idaho National Laboratory. 2015. Plugged In: How Americans Charge Their Electric Vehicles.

Kahn, Ari, and Christina Ficicchia. 2012. The New York City Electric Vehicle Readiness Plan: Unlocking Urban Demand. In Mission Electric: Empire Clean Cities and the Mayor's Office of Long-Term Planning and Sustainability.

Kim, Sungyop, Gudmundur F Ulfarsson, and J Todd Hennessy. 2007. Analysis of Light Rail Rider Travel Behavior: Impacts of Individual, Built Environment, and Crime Characteristics on Transit Access. Transportation Research Part A: Policy and Practice 41 (6):511-522.

LA Metro. 2016a. EV Charging Fact Sheet. In Plug in and Go Metro.

LA Metro. 2016b. Metro EV Charge Stations - Overview. https://www.metro.net/projects/ev/.

LA Metro. 2016c. Metro: Overview. https://www.metro.net/about/agency/mission/.

Lutsey, N. 2015. Transition to a Global Zero-Emission Vehicle Fleet: A Collaborative Agenda for Governments. MBTA. 2014. MBTA Sustainability Report 2014. In MassDOT.

MBTA. 2016. MBTA - About the MBTA - History. http://www.mbta.com/about the mbta/history/?id=970.

McGuckin, Nancy, and Nandu Srinivasan. 2005. The Journey-to-Work in the Context of Daily Travel. Census Data for Transportation Planning Conference.

METRA. 2016. Commuter Rail System Ridership Trends: Annual Report 2015. In Commuter Rail System Ridership Trends.

Mišanović, Slobodan. 2013. Exploitation and Environmentally Aspects of Hybrid Buses in European Cities.

Morrissey, Patrick, Peter Weldon, and Margaret O'Mahony. 2016. Future Standard and Fast Charging Infrastructure Planning: An Analysis of Electric Vehicle Charging Behaviour. Energy Policy 89:257-270.

National Renewable Energy Laboratory. 2015. Key Federal Legislation. http://www.afdc.energy.gov/laws/key legislation.

Noel, Errol C. 1988. Park-and-Ride: Alive, Well, and Expanding in the United States. Journal of Urban Planning and Development 114 (1):2-13.

O'Kelly, Morton E. 1983. Multipurpose Shopping Trips and the Size of Retail Facilities. Annals of the Association of American Geographers 73 (2):231-239.

Offer, GJ, D Howey, M Contestabile, R Clague, and NP Brandon. 2010. Comparative Analysis of Battery Electric, Hydrogen Fuel Cell and Hybrid Vehicles in a Future Sustainable Road Transport System. Energy policy 38 (1):24-29.

Parkhurst, Graham. 1999. Environmental Cost-Benefits of Bus-Based Park and Ride Systems - Including A Review of 'The travel Effects of Park and Ride'. ESRC TSU Research Report 1999/4.

Redenbaugh, Ruth. 2012. Kansas - Missouri Community Readiness for EV and EVSE. In Electrify Heartland Plan: Metropolitan Energy Center.

Schoch, Jennifer. 2016. Modeling of Battery Life Optimal Charging Strategies Based on Empirical Mobility Data. It-Information Technology 58 (1):22-28. doi: 10.1515/itit-2015-0043.

Shen, Wan Xia, Bo Zhang, Yu Feng Zhang, Xue Chao Wang, Qiang Lu, and Cheng Wang. 2015. Research on Life Cycle Energy Consumption and Environmental Emissions of Light-Duty Battery Electric Vehicles. Materials Science Forum.

Spillar, Robert J. 1997. Park-and-Ride Planning and Design Guidelines.

Stieffenhofer, Krae E, Michael Barton, and Vikash V Gayah. 2015. Assessing Park-and-Ride Use and User Reactions to Parking Management Strategies: A Case Study in Puget Sound, Washington. Transportation Research Board 95th Annual Meeting, Washington DC, United States.

Tesla. 2016. The World's Fastest Charging Station. https://www.tesla.com/supercharger.

Tessum, Christopher W, Jason D Hill, and Julian D Marshall. 2014. Life Cycle Air Quality Impacts of Conventional and Alternative Light-Duty Transportation in the United States. Proceedings of the National Academy of Sciences 111 (52):18490-18495.

The EV Project. 2015. What Were the Best Practices Identified for Residential Charger Installations?. 
Todd, Jennifer, and Liz Thorstensen. 2013. Creating the Clean Energy Economy: Analysis of the Electric Vehicle Industry. International Economic Development Council.

Turnbull, Katherine F., Richard H. Pratt, and John E. (Jay) Evans. 2004. Park-and-Ride/Pool: Traveler Response to Transportation System Changes. Transit Cooperative Research Program Report 95.

Tzeng, Gwo-Hshiung, Cheng-Wei Lin, and Serafim Opricovic. 2005. Multi-criteria Analysis of Alternative-fuel Buses for Public Transportation. Energy Policy 33 (11):1373-1383.

U.S. Department of Energy. 1995a. Volume I: General Policy-Level Considerations. In Electric Vehicle Community Market Launch Manual: A Guide to Prepare Your Community for Electric Vehicles.: Electric Transportation Coalition, Electric Vehicle Association of th Americas, U.S. Department of Energy, U.S. Department of Transportation.

U.S. Department of Energy. 1995b. Volume II: The EV-Ready Community: Infrastructure Planning and Development. In Electric Vehicle Community Market Launch Manual: A Guide to Prepare Your Community for Electric Vehicles. : Electric Transportation Coalition, Electric Vehicle Association of th Americas, U.S. Department of Energy, U.S. Department of Transportation.

U.S. Department of Energy. 2015a. Electric Vehicle Charging Station Locations. In Alternative Fueling Station Locator. Alternative Fuels Data Center.

U.S. Department of Energy. 2015b. U.S. HEV Sales by Model. In Alternative Fuels Data Center: Maps and Data. U.S. Deportment of Energy.

U.S. Department of Energy. 2015c. U.S. Plug-in Electric Vehicle Sales by Model. In Alternative Fuels Data Center: Maps and Data. U.S. Deportment of Energy.

U.S. EPA. 2015. GHG Emission Factors Hub. In Center for Corporate Climate Leadership.

Village of Wheeling Board of Trustees. 2012. Village Views: Village of Wheeling Illinois. Village Views.

Vyas, Charul, and Dave Hurst. 2013. Consumer Attitudes, Opinions, and Preferences for Electric Vehicles and EV Charging Stations. In Electric Vehicle Consumer Survey: Navigant Research. 